Please do not remove this page

RMIT

UNIVERSITY

\title{
The effect of liquidity shocks on the bank lending channel: Evidence from India
}

Mishra, Ankita; Burns, Kelly

https://researchrepository.rmit.edu.au/esploro/outputs/9921859109201341/filesAndLinks?institution=61RMIT_INST\&index=null

Mishra, A., \& Burns, K. (2017). The effect of liquidity shocks on the bank lending channel: Evidence from India. International Review of Economics and Finance, 52, 55-76.

https://doi.org/10.1016/j.iref.2017.09.011

Document Version: Accepted Manuscript

Published Version: https://doi.org/10.1016/j.iref.2017.09.011

Repository homepage: https://researchrepository.rmit.edu.au

(C) 2017 Elsevier Inc. All rights reserved.

Downloaded On 2023/04/26 19:15:51 +1000

Please do not remove this page 
Thank you for downloading this document from the RMIT Research Repository.

The RMIT Research Repository is an open access database showcasing the research outputs of RMIT University researchers.

RMIT Research Repository: http://researchbank.rmit.edu.au/

\section{Citation:}

Mishra, A and Burns, K 2017, 'The effect of liquidity shocks on the bank lending channel: Evidence from India', International Review of Economics and Finance, vol. 52, pp. 55-76

See this record in the RMIT Research Repository at:

https://researchbank.rmit.edu.au/view/rmit:4569

Version: Accepted Manuscript

\section{Copyright Statement:}

(C) 2017 Elsevier Inc. All rights reserved.

Link to Published Version:

https://dx.doi.org/10.1016/j.iref.2017.09.011 
The Effect of Liquidity Shocks on the Bank Lending Channel: Evidence from India

Ankita Mishra and Kelly Burns

Dr Ankita Mishra

School of Economics and Finance, RMIT University

Dr Kelly Burns

Curtin Graduate School of Business, Curtin University

\section{Corresponding Author}

Dr Kelly Burns

Curtin Graduate School of Business

Curtin University

78 Murray Street, WA, 6000, Australia

Telephone: + (618) 92664235

E-mail: kelly.burns@ @urtin.edu.au

July 2017 


\begin{abstract}
Using a structural VAR framework and unique bank liquidity index, this study builds a short run model to analyse dynamic interactions among monetary policy, bank liquidity, and bank lending in India. We find that monetary policy shocks have strong initial and persistent impacts on bank lending, while liquidity shocks impact bank lending after a 9-month lag. We also find evidence of an indirect feedback channel between monetary policy and bank lending operating through changes in bank liquidity. However, the indirect effect of monetary policy on bank lending (through bank liquidity) operates with a lag of roughly 6 to 9 months.
\end{abstract}

Keywords: Liquidity index; Monetary policy shocks; SVAR

JEL classification: E52; E58; E47 


\section{Introduction}

The banking sector plays a pivotal role in the transmission of monetary policy. The literature commonly refers to the transmission channel of monetary policy that operates through banks as the 'bank lending channel'. This bank-lending channel operates by affecting the supply of bank loans to the private sector. Since deposits and other sources of funding are imperfect substitutes, a rise in interest rate (or monetary contraction) constrains the liquidity of banks and forces banks to reduce lending to private sector. In turn, this decreases investment and consumption spending and, hence, overall economic activity (Igan et al., 2013). Therefore, banks with large liquid assets are better able to safeguard a fall in bank lending during periods of monetary contraction (Kashyap \& Stein, 2000). ${ }^{1}$

Besides the effect of monetary contraction on the liquidity of the banking sector, several other factors (particularly in emerging market economies) can affect bank liquidity and hence the lending behaviour of banks. As Khwaja \& Mian (2008) point out, these factors relate to regime shifts, exchange rate volatility and speculative banks runs. Several studies in the literature examine the impact of a particular type of liquidity shock to the banking sector and the consequent pass through to borrowing firms. For example, Khwaja \& Mian (2008) examine the impact of a shock to bank liquidity induced by the unexpected nuclear tests carried out by Pakistan in 1998. These nuclear tests led to a collapse in the dollar deposit

\footnotetext{
${ }^{1}$ The same phenomenon has been observed with other banks' characteristics as well, for example, banks with high equity capital to asset ratio (Kishan \& Opiela, 2000), banks affiliated to a holding company (Ashcraft, 2006), and banks that can raise funds from international operations (Cetorelli \& Goldberg, 2012). Another study by Khan et al. (2016) examined the role bank competition for the transmission of monetary policy through bank lending. Taking the sample of the five ASEAN (Association of South East Asian Nations) countries, their study found that changes in the level of competition among banks influences the bank lending channel of monetary transmission.
} 
market, as the Pakistan government restricted the withdrawal of dollar-denominated deposits accounts to local currency at an unfavourable exchange rate. This change in government policy disproportionately affected bank liquidity that relied heavily on dollar deposits. Khwaja \& Mian (2008) find that a percentage point decline in bank liquidity led to $0.6 \%$ decline in bank lending.

Schnabl (2012) examines the international transmission of negative liquidity shocks to international banks, and does so by taking the 1998 Russian debt default as a negative shock to liquidity of international banks and analysing its impact on bank lending in Peru. This study finds that, after the Russian default, lending by international banks to domestically owned Peruvian banks decreased by $61 \%$. The author also finds that Peruvian banks transmitted this liquidity shock to Peruvian firms by reducing their lending. Similarly, Correa-Lopez et al. (2014) analyse the impact of liquidity shocks induced by the rising prospect of European sovereign defaults and changes in US money market regulations in 2011. These changes generated negative liquidity shocks to European banks operating in the US through local branches that relied mainly on time deposits from the US money market as their source of liquidity. In turn, this shock to liquidity resulted in a reduction in branch lending by European banks to US borrowers.

The above discussion highlights that in addition to monetary contraction leading to changes in bank liquidity and hence lending activities; other factors (national and international) can induce a liquidity shock to the banking sector and affect bank lending behaviour. Motivated by the different ways in which changes in both monetary policy and liquidity (because of monetary contraction or other factors) can affect bank lending and cause significant effects on economic activity, this study estimates separately the effects of monetary policy shocks 
and liquidity shocks on bank lending within the same modelling framework. In particular, it analyses the effect of monetary contraction on bank lending (bank lending channel) and the effects of liquidity shocks (exogenous to monetary policy changes) on bank lending. Finally, by using a hypothetical scenario in its model, the study attempts to quantify the effect on bank lending due to a squeeze in liquidity following a monetary policy contraction.

Before we can examine the effect of monetary policy shocks on bank liquidity and hence on bank lending behaviour, several other issues need to be tackled. In addition to their effects on the supply of credit, monetary policy changes can influence the 'demand for credit'. The monetary policy channel that affects the demand for loans is called the balance sheet channel $^{2}$. The reason that monetary contraction worsens the balance sheet of firms is that reduced cash flows or a decline in equity prices leads to a fall in net worth of firms (Mishkin, 1996). In addition, the higher cost of borrowing reduces demand for credit, hence reducing investment and aggregate economic activity. Thus, contractionary monetary policy works both ways by affecting the supply of credit as well as the demand of credit. Therefore, in order to analyse the effect on bank lending behaviour due to monetary policy shocks, the effect of these shocks on the demand for loans must be controlled for. There is ample literature on the monetary transmission mechanism that proves that loan demand conditional on banks' characteristics is homogenous (Bluedorn et al., 2013; Ashcraft, 2006; Jayaratne \& Morgan, 2000). Given homogenous demand for loans, any change in the lending response of banks due to monetary policy shocks can be attributed to a monetary transmission mechanism working through the supply of loans. Under the assumption of homogenous loan demand for banks with similar characteristics, the first major challenge is to extract the group of banks

\footnotetext{
${ }^{2}$ For more details on complementary explanations (from macroeconomic theory) on bank lending channel and credit or balance sheet channel, refer to Scharler (2008).
} 
that share similar characteristics on one hand, and forms the sizeable portion of banking sector on the other.

The other important challenge is to extract the monetary policy shocks that are exogenous to other relevant macroeconomic variables (mainly inflation and output as suggested by the Taylor rule (1993)) to which the central bank responds. These macroeconomic variables may also be determinants of bank lending along with changes in monetary policy. This raises the possibility that changes in bank lending behaviour due to monetary policy changes confound the effect of monetary policy and other lending drivers (Bluedorn et al., 2013). Therefore, without the proper extraction of monetary policy changes exogenous to these variables, their effect on bank lending behaviour that is solely due to changes in monetary policy cannot be ascertained $^{3}$.

Taking note of the above concerns, this paper empirically examines the effects of monetary policy shocks on the liquidity of the banking sector and the consequent pass through of these shocks to the loan supply. For this analysis, we take India as our case study for several reasons. India is a growing, emerging market economy and, more importantly, banks are an important source of credit in that country. Hence, bank lending plays a pivotal role in the transmission of monetary policy (Bhaumik et al., 2011). Further, commercial banks in India dominate the financial sector, comprising more than three fifths of financial system assets (Financial Stability Report of Reserve Bank of India (RBI hereafter), 2010). The group of commercial banks in India consists of public sector banks as well as private sector banks,

\footnotetext{
${ }^{3}$ The study by Kwapil \& Scharler (2013) for the developed economies like UK and USA also suggested that the pass through of changes in monetary policy rates to lending rates of banks differs and this pass through depend on whether the monetary policy changes are expected or unexpected.
} 
including foreign banks. However, all banks compete on a level playing field. These state owned or private banks are autonomous and driven by the underlying motive of profit. Commercial banks in India can be regarded as more or less homogenous with an underlying focus on profitability (Bhaumik et al., 2011). ${ }^{4}$ As noted above, commercial banks in India represent a sizeable portion of the financial (or banking) sector in India. Given this, we take these banks as representative of the banking sector for the Indian economy.

To estimate the effect of monetary policy shocks on bank liquidity and lending, we need to identify exogenous changes in monetary policy (i.e. changes in monetary policy that are independent of the state of the economy). With endogenous changes in monetary policy (the changes in response to the economy), it is not possible to disentangle loan demand changes from loan supply changes, and the full effect of monetary policy on bank lending cannot be estimated (Bluedorn et al., 2013). ${ }^{5}$ To identify monetary policy shocks, we adopt a structural vector autoregression approach (SVAR), with contemporaneous restrictions and underlying assumptions on the central bank's (the RBI in this case) feedback rule or reaction function, and structure of the economy. Our identification strategy is based on the scheme proposed by Mishra \& Mishra (2012); as such, it is able to capture the monetary transmission mechanism for India without giving rise to empirical anomalies. We use this model to build a scenario by applying appropriate restrictions on contemporaneous causality to analyse and quantify the

\footnotetext{
${ }^{4}$ However, there might be differences in the customer base between the public sector banks and private sector banks (Bhaumik et al., 2011).

${ }^{5}$ However, sluggishness in bank lending following monetary contraction may also come from factors such as loans under commitment (see, e.g. Bernanke \& Blinder, 1992; Morgan, 1998; Kishan \& Opiela, 2000), but a part of the sluggishness in bank lending behaviour is attributable to policy changes that are endogenous to other macroeconomic fundamentals (Bluedorn et al., 2013).
} 
indirect pass through of monetary policy shocks to bank lending through changes in bank liquidity following these shocks.

Our study makes several notable contributions to the literature. First, instead of using a single measure of bank liquidity, we construct a bank liquidity index using factor analysis. Theoretically, the composite measure of liquidity is better suited to indicate the overall state of liquidity in the banking sector as compared to individual variables (Gadanecz \& Jayaram, 2009). Second, our study builds a comprehensive short run VAR model to identify the exogenous changes in monetary policy, and uses these monetary shocks to analyse the effects of monetary policy on bank liquidity and lending within the same modelling framework. Third, our modelling strategy enables us to separate out the effects of liquidity shocks and monetary policy shocks on bank lending activities and underlying lags in the pass through of these effects. Fourth, by exploiting the contemporaneous causality structure, we attempt to provide evidence (for/against) on the indirect feedback channel between monetary policy and bank lending that operates through changes in liquidity.

We do acknowledge some limitations of the present study, which provide scope for further research. First, in this study, we use the aggregate bank level data to analyse the effect of monetary policy on bank liquidity and lending but we do accept the possibility of cross sectional asymmetries existing in the loan responses of banks giving rise to asymmetric effects of monetary policy (Kishan \& Opiela, 2006). We further accept the possibility that even at the aggregate level, the reaction of banks to monetary policy changes may be asymmetric, i.e., lending responses of banks to monetary policy can be different in easy and tight monetary policy regimes (Bhaumik et. al, 2011). Second, we note that some studies in recent times emphasize the need to take into account changes in banks' business model and 
link between bank risk and monetary policy before analysing the bank-lending channel of monetary policy. As noted by Gambacorta \& Marques-Ibanez (2011), while analysing the bank-lending channel, bank risk should be considered along with other bank specific characteristics. This is mainly due to financial innovations, and variables capturing bank size, liquidity and capitalization (the standard indicators used in the bank lending channel literature) may not be adequate for the accurate assessment of banks' ability and willingness to supply additional loans (Gambacorta \& Marques-Ibanez ,2011). Taking note of these limitations of the study, our main contribution lies in separating exogenous monetary changes and liquidity shocks and analysing separately the effects of these shocks on aggregate bank lending. The sample period for this study is December 1996 to December $2012 .^{6}$

The remainder of the paper is organised as follows: Section 2 provides background information on commercial banking, monetary policy framework, choice of monetary policy instrument and the lending behaviour of the commercial banks in India; Section 3 presents a short note on empirical techniques as employed in this study; Section 4 describes the data and sets up the empirical model; Section 5 presents the main results; Section 6 discusses the results; and Section 7 concludes.

\section{Indian Context}

\subsection{Commercial Banks in India}

The banking sector in India is divided into two broad groups, that is, commercial banks and co-operative banks, of which the former accounts for more than $90 \%$ of the country's

\footnotetext{
${ }^{6}$ The reasons for choosing this sample period for Indian context are cited in section 4.
} 
banking system's assets (Financial Stability Report of the RBI, 2010). ${ }^{7}$ Commercial banks in India comprise nationalised banks (majority equity holding with the government), the State Bank of India (SBI) (majority equity holding with the RBI), the associate banks of SBI (majority equity holding with the SBI), Indian private banks and foreign banks. ${ }^{8}$ The public sector banks (PSBs) (nationalised banks, SBI and its associate bank) dominate the commercial banking space, comprising close to $72 \%$ of total commercial bank assets (Financial Stability Report of the RBI, 2010).

In the pre-reform period before 1991, the banking sector in India catered for the needs of planned development in a mixed economy framework where the government was a dominant player in economic activity. The government used the banking sector as a captive source of funds by means of a statutory liquidity ratio (SLR). ${ }^{9}$ The SLR allocated a larger share of banks' resources to government and the SLR requirement continued to increase, reaching a peak of $38.5 \%$ in 1989 to 1990 . In 1992, banking sector reforms were initiated based on the recommendations of Narsimham Committee I. The main recommendations of the committee were to reinstate the Cash Reserve Ratio $(\mathrm{CRR})^{10}$ as an instrument of monetary policy (and

\footnotetext{
${ }^{7}$ It should be noted that commercial banks in India also include local area banks (LABs) and Regional Rural Banks (RRBs). However, all the banking statistics reported by RBI on commercial banking sector in India exclude LABs and RRBs. Hence, all the information and statistics reported and used in this paper similarly exclude LABs and RRBs from the commercial banking sector.

${ }^{8}$ Refer to Figure 2.1 (pp. 19 in Manual on Banking and Financial Statistics, 2007: the RBI Publication) for diagrammatic representation of the Indian banking structure.

${ }^{9}$ At the close of business every day, all banks operating in India are required to maintain a minimum proportion of their Net Demand and Time Liabilities as liquid assets in the form of cash, gold and unencumbered approved securities. The ratio of liquid assets to demand and time liabilities is known as Statutory Liquidity Ratio (SLR).

${ }^{10} \mathrm{CRR}$ is the specified minimum fraction of the total deposits of commercial banks that these banks have to hold as cash or as deposits with the RBI, and is considered equivalent to holding cash with the RBI. Before
} 
not as a means of controlling the secondary expansion of credit brought about by monetisation of the fiscal deficit), bring down the Statutory Liquidity Ratio (SLR) ${ }^{11}$ in a phased manner, and phase out the direct credit program to the priority sector by the commercial banks. ${ }^{12}$ Further, the committee recommended deregulating interest rates and dismantling the policy of concessional interest rates on Government borrowing to bring it into line with the market determined rate of interest. The committee also proposed liberalising policies towards foreign banks with regard to opening offices, branches and subsidiaries. Consequently, reforms in the banking sector were carried out along these lines. The legislative framework governing PSBs was also amended in 1994 to enable banks to raise capital funds from the market by way of public issue of shares. The government initiated the legislative process to reduce the minimum Government ownership in nationalised banks from $51 \%$ to $33 \%$ without altering their public sector character. Steps were also taken to infuse competition into the financial system. The RBI issued guidelines in 1993 with respect to the establishment of new banks in the private sector. Likewise, foreign banks were given more liberal entry and the norms for entry of new private banks were established (Mishra, 2013). In 1998, the second generation of banking sector reforms was initiated based on the recommendation of Narsimham Committee II. The main feature of second-generation banking reforms was the creation of asset reconstruction companies

2006, the RBI could prescribe CRR for commercial banks between 3-20 per cent of their total demand and time liabilities. However, with the RBI Amendment Act (2006), RBI can now prescribe (keeping in view the monetary stability of the country) CRR for commercial banks without any floor and ceiling rate.

${ }^{11}$ The present rate of SLR is 21.5 per cent (as at February 2015).

12 The priority sector broadly comprises agriculture, small-scale industries, small road and water transport operators (owing up to 10 vehicles), small business (original cost of equipment used for business not exceeding 2 million Indian rupee), retail trade, professional and self-employed persons, state sponsored organisations for Scheduled Castes and Scheduled Tribes, education, housing, weaker sections and export oriented industries. 
(ARC) to improve the quality of the balance sheet of the commercial banks. Hence, by 1996, commercial banks in India had become more or less independent in their operations (Bhaumik et al., 2011).

\subsection{Monetary Policy Framework in India and Selection of Monetary Policy}

\section{Instrument}

At the beginning of the planning period in the 1950s, monetary policy in India was mainly determined by the government's fiscal stance and was formulated against the backdrop of large fiscal deficits. In the second half of the 1980s, India adopted a 'monetary targeting' framework with annual growth in broad money as an intermediate target. After a balance of payments crisis in 1991, India adopted economic reforms that led to a distinct change in the early 1990s policy environment, framework and strategies. Monetary policy then had to deal with traditional issues alongside new issues brought about by the changed economic policy environment. Indeed, deregulation and liberalisation of financial markets cast doubt on the appropriateness of exclusive reliance on money as the only intermediate target in the late 1990s. The expansion of money supply emanating from monetisation of the government deficit and rising capital inflows rendered the control of monetary aggregates more difficult. The transition of economic policies from a controlled to a liberalised but regulated regime is reflected in the changes in monetary management in India. In 1998 to 1999, the monetary policy framework in India changed from a 'pure monetary targeting strategy' to a Multiple Indicator Approach (MPA). Although the basic objectives of monetary policy of ensuring price stability and availability of credit to productive sectors remained intact, the underlying operating procedures underwent significant change. Emphasis shifted from direct instruments of monetary policy (interest rate regulations, selective credit controls and cash reserve ratio 
(CRR)) to indirect instruments (repo operations under liquidity adjustment facility (LAF) and open market operations (OMO)).

The Liquidity Adjustment Facility (LAF) was introduced in 2000 and enabled the RBI to manage liquidity on a daily basis by absorbing and injecting liquidity through repo and reverse repo operations on a variable interest rate basis. The LAF also helped to keep movements of the overnight call rate within a specified band, and provided monetary authorities with greater flexibility in determining both the quantum of adjustment and rates by responding to the needs of the system on a daily basis (Mishra \& Mishra, 2012). In the post LAF period, the repo rate emerged as the main instrument along with the lending rate of the RBI, thus replacing the bank rate for all practical purposes (Aleem, 2010). However, as Bhaumik et al. (2011) point out, CRR was not completely abandoned as an instrument of monetary policy and is still used in situations that demand a significant monetary policy response.

In the light of the above discussion, it is difficult to select one indicator as an instrument of monetary policy for India. Several studies (e.g. Mishra \& Mishra, 2012; Singh \& Kalirajan, 2007) suggest that in the post reform period interest rates emerged as the main instrument in signalling the monetary policy stance. Although the policy rates (namely, bank rate and repo rate) signal the monetary policy stance, expectations about monetary policy are formed through the overnight call money rate (CMR). The CMR is also the most closely watched variable in the day-to-day conduct of monetary operations and has emerged as an informal operating target since the operationalisation of the LAF system (Aleem, 2010). Many studies on monetary policy in India have applied the CMR as a proxy measure of monetary policy in India. For example, Virmani (2004) uses the CMR as a proxy measure of monetary policy to 
estimate monetary rules; Kannan et al. (2007) use the CMR as a proxy measure of monetary policy to construct the monetary conditions index; Aleem (2010) uses CMR as a proxy measure of monetary policy to examine the transmission mechanisms of monetary policy; and Mishra \& Mishra (2012) use the CMR as a proxy measure of monetary policy to model the reaction function of the RBI. The CMR becomes even more relevant in the present study given that the primary objective of our research is to analyse the dynamic interaction that occurs among monetary policy, liquidity and bank lending. The RBI mainly influences liquidity in the economy through intervention in the money market. Thus, for our research purposes, the CMR appears the most suitable indicator of the stance of monetary policy. ${ }^{13}$

\subsection{Lending Behaviour of Banks and Monetary Transmission in India}

Banks play a dominant role in financing economic activities and ill functioning banking sector has been a major source of financial crisis, including the most recent financial crisis of 2007-2009 in both developed and emerging economies (Drakos \& Kouretas, 2015). This is particularly true for India where, despite the recent upsurge in equity and debt financing, the share of banks in domestic corporate borrowing has remained high (Chapter 1V, Chart IV.1, pp. 44, Patel Committee Report ${ }^{14}$ ). At the aggregate level, the two most important factors

\footnotetext{
${ }^{13}$ We also tried 'yield of SGL transactions on treasury bills of 91 days (91 day Treasury bill rate)' as a monetary policy instrument. The model with 91-day Treasury bill rate gave theoretically inconsistent responses of output and exchange rate to monetary policy shocks. This may be because in the period considered here, the monetary policy stance of the RBI was the provision of adequate liquidity to meet credit growth and support investment demand and to keep vigil on the prices and exchange rate. The RBI mainly influences liquidity in the economy to achieve the mentioned objectives and to influence liquidity the RBI intervenes through the money market.
}

\footnotetext{
${ }^{14}$ Patel Committee Report refers to Report of the Expert Committee to Revise and Strengthen the Monetary Policy Framework, submitted to the RBI Jan21, 2014, available at
} 
relating to lending activities of commercial banks are; lending rates and statutory pre-emption through SLR. These factors influence the credit disbursal by banks and influence the efficacy of monetary transmission.

In July 2010, the RBI initiated a 'base rate' system to enhance transparency in lending rates of banks and thus enable a better assessment of the transmission of monetary policy. The 'base rate' is the minimum rate at which a bank can lend. Banks determine their lending rates with reference to the 'base rate'. Though banks are free to decide their own base rate, they have to take into account certain factors like their cost of funds, adjustment cost for complying with CRR and SLR requirements, overhead costs and profit margins. Banks often use average cost of funds rather than marginal cost of funds to calculate their cost of funds. This is taken to be one of the potential reasons for the lack of responsiveness of their base rate to monetary policy changes (Das et al., 2015). SLR requirements suppress the cost of borrowing for the government and reduce the funds available with banks to lend to private borrowers. This constrains the transmission of interest rate changes through term structure. ${ }^{15}$ As discussed above, the SLR prescription has gradually been reduced over the years as the part of banking reforms. However, it has been observed that banks have voluntarily invested in government securities above the statutory prescription (refer to table IV.3, pp. 47 in Patel Committee Report). The reason for this excess holding of SLR securities, as cited in the Patel Committee Report to the RBI, is the fact that these securities serve as the only collateral to avail central bank resources under the LAF. This behaviour of banks to invest more than the required proportion of their assets in risk free government securities reflects their 'risk averse' attitude and is known as 'lazy banking' in Indian policy circles. The main excuses

\footnotetext{
https://rbidocs.rbi.org.in/rdocs/PublicationReport/Pdfs/ECOMRF210114_F.pdf

${ }^{15}$ For more discussion on impediments to monetary transmission in India, refer to 'Chapter IV: Addressing Impediments to Monetary Policy’ in Patel Committee Report
} 
given for this 'lazy banking' are the risk associated with credit disbursal in a developing country along with associated economic cycles, lack of expertise to screen potential borrowers and underdeveloped institutions to enforce contracts (Bhaumik \& Piesse (2008)). Several other studies in the literature examine the bank lending responses to monetary policy changes using bank level data. For example, Bhaumik et al. (2011) analyse the impact of ownership on the reaction of banks to monetary policy. They found ownership to have a significant effect on banks' response to monetary policy. Their findings also suggest monetary policy changes have different implications for less risky (short term) lending and relatively more risky (medium term) lending. Overall, their study found support of the view that monetary tightening by the central bank leads to a reduction in credit disbursal by Indian banks. Another study by Nachane et.al (2006) demonstrated that whether monetary policy will be effective in influencing bank lending depends on various factors including credit quality of bank assets, the relative liquidity of banks' balance sheet, and whether banks are constrained by risk based capital standards. Going further down the segregation, Das et al. (2015) analyse the transmission of monetary policy at intra-bank level using branch-lending data. Their study finds evidence in support of cross-sectional differences in lending behaviour within banks in their response to monetary policy and these differences, in turn, can be explained by several branch level asset, liability and organizational variables. Given this background, in this study we will explore the effects of monetary policy shocks on banks' aggregate lending through their effect on bank liquidity. 


\section{Empirical Strategy}

\subsection{Construction of Liquidity Index}

We construct a liquidity index for Indian commercial banks using factor analysis. Factor analysis clusters the observable variables into homogeneous data sets and creates new variables (factors) from which an index can be constructed. This factor analysis is performed on four observable variables for which the monthly data is consistently available from 1990 onwards. These variables are liquid assets to total assets, cash in hand to demand deposits, liquid assets to demand deposits, and liquid assets to total deposits. Demand deposits represent short-term liabilities of banks, while the sum of cash-in-hand and balances with RBI of commercial banks represent the 'liquid assets' of banks. These variables serve as very basic indicators as defined in the 'core set' of the International Monetary Fund's (IMF) Financial Soundness Indicators (FSI) to gauge the liquidity of the banking sector. ${ }^{16}$ 'Liquid assets', as taken here, constitute a very restrictive measure of bank liquidity. ${ }^{17}$ Therefore, the liquidity index represents the prohibitive scenario for banks' liquidity, and the results should be interpreted as the outcome in a least favourable scenario. We adopt four liquidity indicators in such a way that any increase in the ratio implies improved liquidity for the banking sector. The index takes values ranging from 0 to 100 . A higher liquidity index implies higher bank liquidity and vice versa. Detailed methodology of the construction of the liquidity index is provided in 'Appendix: Methodology/Description'.

\footnotetext{
${ }^{16}$ Refer to Compilation Guide for Financial Soundness Indicators (IMF, 2006)

${ }^{17}$ For a more broadly based definition of liquid assets, refer to Financial Stability Report (the RBI, 2014). However, given the monthly nature of exercise and long-time series requirement, we could find only the above stated variables to define 'liquid assets'.
} 
Figure 1 presents the final liquidity index and its constituent variables. Looking at the trends, it can be observed that liquidity index and its constituents' recorded high values during the early to mid-nineties in line with the high CRR and SLR requirements. On average, liquid assets to total assets, deposits and demand deposits (short term liabilities of the banks) were around $11 \%, 15 \%$ and $87 \%$, respectively, from 1990 to 1995 . Consequently, the constructed liquidity index also registered high values in the range of 70 to 80 during that period. Following banking sector reforms and phased reduction in CRR and SLR requirements, liquidity holdings by banks had gone down from 1996 onwards and more funds became available for lending and other investment purposes. This shift is reflected in the constructed liquidity index and its constituents. The ratio of liquid assets to total assets, deposits and demand deposits, on average, was around 8\%, 10\% and 65\% during 1996 to 2000, and went down further to $5 \%, 7 \%$ and $45 \%$ during 2000 to 2007 . Correspondingly, the liquidity index hovers in the range of 40 to 30 from 1996 to 2000, and 25 to 15 from 2000 to 2007.

As the global financial landscape had undergone a major shift and faced a crisis of unprecedented extent in 2008, the stance of monetary policy shifted towards imparting greater stability to the financial system. The Reserve Bank of India pursued the policy of active demand management of liquidity through appropriate use of the CRR stipulations and OMO including the MSS and LAF. Consequently, the CRR had been raised several times from March 2007 to October 2008 (refer to chapter II, The RBI, Report on Trend and Progress of Banking in India (2007-08)), resulting in increased holdings of liquid assets by commercial banks. This shift is reflected in our 'constructed liquidity index' that increased and hovered in the range of 35 to 45 , up from the earlier range of 15 to 25 . 
The year 2009 witnessed spill over effects of the financial crisis requiring swift and appropriate policy measures. Proportionately, the stance of monetary policy switched from tightening to easing from late 2008 and measures were taken to release liquidity holdings of commercial banks ensuing sufficient flow of credit to crisis affected sectors (refer to chapter III, The RBI, Report on Trend and Progress of Banking in India (2008-09)). Therefore, our 'constructed liquidity index' declined from late 2008 to late 2009, and was in the range of 18 to 20 .

In line with the global outlook towards improving liquidity risk management and exposure of the banking sector following the crisis (Box III.1, Chapter III, The RBI, Report on Trend and Progress of Banking in India (2009-10)), there was a renewed push on adequate liquidity holdings by banks. This shift is reflected in our 'constructed liquidity index', which increased to be in the range of 40 to 30 from 2010 onwards. 


\section{Figure 1:}

Constructed Liquidity Index (with its constituent variables) for Commercial Banks in

\section{India}

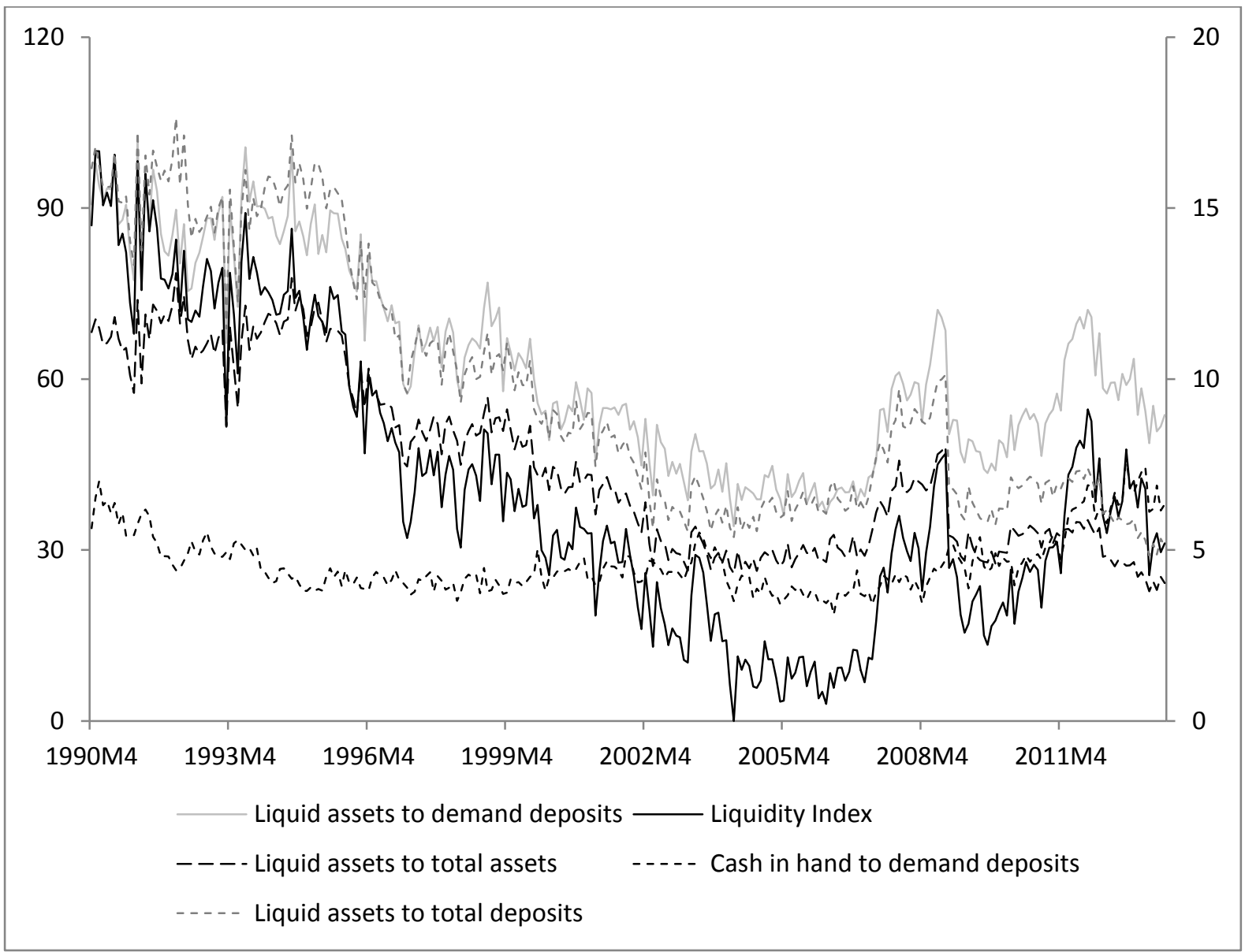

Notes:

Liquidity Index and liquid assets to demand deposits are plotted on primary Y-axis while other constituent ratios are plotted on secondary $\mathrm{Y}$ axis.

\subsection{Identification of Monetary Policy Shocks and Vector (and Structural)}

\section{Autoregression Techniques}

\section{Identification of Monetary Policy Shocks}

The monetary policy shock is identified as the disturbance term in an equation of the form:

$$
S_{t}=f\left(\Omega_{t}\right)+\sigma_{s} \varepsilon_{t}^{S}
$$


Here $S_{t}$ is the instrument of monetary policy and $f$ is a linear function that relates $S_{t}$ to the information set $\Omega_{t} \cdot{ }^{18}$ The random variable $\sigma_{s} \varepsilon_{t}^{S}$ is a monetary policy shock. ${ }^{19}$ We find that extracted shocks signal well the monetary policy stance of the RBI at various time intervals.

\section{$\underline{\text { Vector Autoregression (VAR)/ Structural Vector Autoregression (SVAR) Models }}$}

A VAR is a convenient device to summarise first and second order moment properties of the data. The basic problem with the VAR is that a given set of second moments is consistent with many dynamic response functions. This shortcoming is overcome by defining the VAR in terms of mutually uncorrelated innovations and placing identification restrictions on the system of dynamic simultaneous equations. Sims (1980) popularised the method of using Cholesky decomposition of innovations or in other words, imposing a recursive structure for the corresponding dynamic structural equation model.

An alternative to the recursive VAR or temporal ordering of variables is to allow for a more elaborate set of restrictions guided by economic theory. This is referred to as a structural VAR (SVAR) ${ }^{20}$. The SVAR approach integrates the need to identify the causal impulse

\footnotetext{
${ }^{18}$ The equation for monetary policy instrument, taken as reaction function of central bank in SVAR models, is 'reaction function in surprises' (Clarida, 2001). This equation models unexpected discretionary monetary policy actions as a function of unexpected changes in output, inflation and exchange rate variables (in our model).

${ }^{19}$ The estimated shocks using equation 1 are plotted in appendix figure $\mathrm{A} 1$ and related discussion is provided in 'Appendix: Methodology/Description', section 'Note on estimated Monetary Policy Shocks' for interested readers.

${ }^{20}$ Details on econometric aspects of VAR/SVAR modelling along with related equations are provided in 'Vector Autoregression (VAR) / Structural Vector Autoregression (SVAR) Models' section in Appendix:Methodology/Descrioption'.
} 
response functions into the model specification and estimation process. Sufficient identification restrictions can be obtained by placing either short run or long run restrictions on the model. In this exercise we make use of the structural vector autoregression with short run restrictions. $^{21}$

\section{Data and Empirical Models}

The model used here consists of eight variables, which are chosen to extract the monetary policy shocks and analyse the consequent effect of these shocks on bank liquidity and bank lending. ${ }^{22}$ The eight variables of the model consist of two foreign variables and six domestic variables. These form two blocks in the model; one is the foreign block with two variables, and the other is the domestic block with six variables. The two foreign variables are the world commodity price index and federal funds rate. World commodity prices represent global inflation and, with growing linkage of the domestic economy to the world economy (Mishra, 2013), it has become an important variable in RBI's information set to consider when setting

\footnotetext{
${ }^{21}$ We place short run restrictions to identify monetary policy shocks and do not go into the long run restrictions structure, which provides for an interesting avenue to explore in future. As we limit ourselves to short run (that is, the period up to two year), we do not consider issues related to cointegration, which refers to the existence of long run equilibrium. Besides the short run focus of our model, the necessary precondition of all the time series being non-stationary for VECM modelling is not met. Therefore, we proceed with SVAR modelling framework where restrictions on short run parameters are derived from the structure of Indian economy and assumptions on reaction function of the central bank.
}

\footnotetext{
${ }^{22}$ The structure of the model to extract monetary policy shocks is based on identification strategy applied in Mishra \& Mishra (2012).
} 
monetary policy. ${ }^{23}$ Federal funds rate is taken as a proxy for international interest rates, mainly because the monetary policy of Federal Reserve Bank acts as an external constraint on the monetary policy of the RBI (Aleem, 2010). Therefore, these two variables enter in the information set of RBI in our framework (refer to equation 1) before it sets monetary policy. The six domestic variables are: inflation (measured as the rate of change in wholesale price index (WPI)); output gap (measured as the difference between (log of) gross domestic product (GDP) at factor cost and its (log of) Hodrick-Prescott trend) ${ }^{24}$ exchange rate (as measured by the nominal effective exchange rate (NEER)); monetary policy instrument; bank liquidity index; and gross bank credit (or lending). Call money rate (CMR) is used as the instrument of monetary policy. ${ }^{25}$ The foreign block variables are exogenous to the system. It implies that domestic variables are not entering into the equations of foreign variables either contemporaneously or with a lag. This assumption is made due to the small size of the Indian economy relative to the world economy, which makes it unlikely that domestic variables can explain movements in foreign variables either contemporaneously or with a lag.

The data for the domestic variables (except for GDP) is collected from the annual Handbook of Statistics on the Indian Economy (The RBI, 2013). The GDP data is sourced from the IMF International Financial Statistics (CD-ROM). The commodity price index is the Commodity

\footnotetext{
${ }^{23}$ Instead of using oil prices inflation as used in Mishra \& Mishra (2012), we use global commodity inflation as used in Aleem (2010) for a closely related research objective. Further, in our framework oil prices enter into the system through WPI inflation.

${ }^{24}$ The GDP figures are available per quarter only. These quarterly GDP figures are converted into a monthly time series using a continuous time-dynamic interpolation method (Moosa \& Burns, 2012).

${ }^{25}$ We re-emphasise that CMR is not the instrument of monetary policy. Rather, it is only an indicator of monetary policy stance and the prevailing liquidity situation in the economy. At the most, it can act only as a proxy for the instrument of monetary policy.
} 
Research Bureau (CRB) BLS commodity price index. ${ }^{26}$ Federal funds rate (a proxy for foreign interest rate) is the US federal funds target rate - middle rate. ${ }^{27}$ The data on these two foreign variables is collected from DataStream. The sample period covers December 1996 to December $2012 .^{28}$ There are three compelling reason to commence the analysis from 1996. First, the macro-stabilisation program undertaken after the balance-of-payment crisis in 1991 started to show its effect after 1995 (Mishra and Mishra, 2012). Second, commercial banks in India became autonomous in their operations roughly from 1996 onwards. Third, the quarterly GDP series for India is available only from the third quarter of 1996.

We use the following contemporaneous restriction matrix $P^{29}$ in the benchmark case to isolate the monetary policy shocks and analyse the impact of these shocks on bank liquidity and lending:

\footnotetext{
${ }^{26}$ More information on this index is available at http://www.crbtrader.com/crbindex/spot_background.asp

${ }^{27}$ The federal funds rate is the interest rate at which depository institutions lend balances at the Federal Reserve to other depository institutions overnight. The daily effective federal funds rate is a weighted average of rates on trades through NY brokers. Weekly figures are averages of 7 calendar days ending on Wednesday of the current week; monthly figures include each calendar day in the month. The Fed Funds Target Rate is the Federal Reserve's desired target rate for the Fed Funds Rate.

${ }^{28}$ It has to be noted that we did subsample analysis also, with the sample starting from 2000 given that some significant changes took place in Indian monetary policy regime roughly around that time (refer to section 2.2). However, we did not notice any significant change in the results from the subsample commencing from 2000. Therefore, the results from the full sample are provided.

${ }^{29}$ Refer to 'Vector Autoregression (VAR) / Structural Vector Autoregression (SVAR) Models' section in Appendix:Methodology/Descrioption'
} 
Benchmark (Identification) Case

$$
\mathrm{P}=\left(\begin{array}{cccccccc}
a_{11} & 0 & 0 & 0 & 0 & 0 & 0 & 0 \\
\mathrm{a}_{21} & \mathrm{a}_{22} & 0 & 0 & 0 & 0 & 0 & 0 \\
\mathrm{a}_{31} & \mathrm{a}_{32} & \mathrm{a}_{33} & 0 & 0 & 0 & 0 & 0 \\
\mathrm{a}_{41} & \mathrm{a}_{42} & \mathrm{a}_{43} & \mathrm{a}_{44} & 0 & 0 & 0 & 0 \\
\mathrm{a}_{51} & \mathrm{a}_{52} & \mathrm{a}_{53} & \mathrm{a}_{54} & \mathrm{a}_{55} & 0 & 0 & 0 \\
\mathrm{a}_{61} & \mathrm{a}_{62} & \mathrm{a}_{63} & \mathrm{a}_{64} & \mathrm{a}_{65} & \mathrm{a}_{66} & 0 & 0 \\
\mathrm{a}_{71} & \mathrm{a}_{72} & \mathrm{a}_{73} & \mathrm{a}_{74} & \mathrm{a}_{75} & \mathrm{a}_{76} & \mathrm{a}_{77} & 0 \\
\mathrm{a}_{81} & \mathrm{a}_{82} & \mathrm{a}_{83} & \mathrm{a}_{84} & \mathrm{a}_{85} & \mathrm{a}_{86} & \mathrm{a}_{87} & \mathrm{a}_{77}
\end{array}\right)\left(\begin{array}{c}
\text { com } \\
\text { ffrate } \\
\text { outputgap } \\
\text { inf } \\
\text { er } \\
\text { mp } \\
\text { liq } \\
\text { gbl }
\end{array}\right)
$$

Here, 'com' is the world commodity prices, 'ffrate' is the federal funds rate, 'inf' is WPI inflation, 'er' is exchange rate measured by NEER, ' $m p$ ' is the proxy measure for the monetary policy instrument (the call money rate), ' $l i q$ ' is liquidity index of commercial banks, and ' $\mathrm{g} b l$ ' is gross bank lending. The non-zero coefficients $a_{i j}$ in the above structure indicates that variable ' $j$ ' affects variable ' $i$ ' instantaneously. International shocks can affect the domestic economy rapidly; thus, as the foreign block variables have an instant effect on all the variables in the domestic block, they are ordered first. The equation for ' $m p$ ' is the monetary policy instrument equation, as defined by equation 1 . The monetary policy instrument equation reflects that it is set after looking at current values of inflation, output gap and exchange rate. This assumption is valid for a developing economy such as India, where the central bank has multiple objectives. ${ }^{30}$ Ordering among the three policy variables (namely, output gap, inflation and exchange rate) is based on the results of pair-wise Granger causality tests. ${ }^{31}$ Following equation 1 and taking CMR as the instrument of monetary policy, shocks in this equation are classified as 'monetary policy shocks'. These are exogenous shocks to monetary policy, independent of the state of the economy as characterised by three

\footnotetext{
${ }^{30}$ For more details on the validity of this assumption in Indian context refer to Mishra \& Mishra (2012).

${ }^{31}$ The results of Granger causality tests are provided in Appendix, Table A3.
} 
key macroeconomic variables: inflation, output gap and exchange rate. Consequently, bank liquidity and gross bank lending are ordered after the monetary policy instrument to analyse the effect of these shocks on bank liquidity and lending.

The benchmark case provides the building blocks for the alternative scenario. In this scenario, we do not allow monetary policy shocks to enter into the bank lending equation contemporaneously. This enables a quantification of the pass through of monetary policy shocks to bank lending through liquidity shocks. In order to build the above scenario, contemporaneous restriction matrix $P$ is modified in the following way:

Alternative Case: no contemporaneous feedback from monetary policy to bank lending

$$
\mathrm{P}=\left(\begin{array}{cccccccc}
a_{11} & 0 & 0 & 0 & 0 & 0 & 0 & 0 \\
\mathrm{a}_{21} & \mathrm{a}_{22} & 0 & 0 & 0 & 0 & 0 & 0 \\
\mathrm{a}_{31} & \mathrm{a}_{32} & \mathrm{a}_{33} & 0 & 0 & 0 & 0 & 0 \\
\mathrm{a}_{41} & \mathrm{a}_{42} & \mathrm{a}_{43} & \mathrm{a}_{44} & 0 & 0 & 0 & 0 \\
\mathrm{a}_{51} & \mathrm{a}_{52} & \mathrm{a}_{53} & \mathrm{a}_{54} & \mathrm{a}_{55} & 0 & 0 & 0 \\
\mathrm{a}_{61} & \mathrm{a}_{62} & \mathrm{a}_{63} & \mathrm{a}_{64} & \mathrm{a}_{65} & \mathrm{a}_{66} & 0 & 0 \\
\mathrm{a}_{71} & \mathrm{a}_{72} & \mathrm{a}_{73} & \mathrm{a}_{74} & \mathrm{a}_{75} & \mathrm{a}_{76} & \mathrm{a}_{77} & 0 \\
\mathrm{a}_{81} & \mathrm{a}_{82} & \mathrm{a}_{83} & \mathrm{a}_{84} & \mathrm{a}_{85} & 0 & \mathrm{a}_{87} & \mathrm{a}_{77}
\end{array}\right)\left(\begin{array}{c}
\text { com } \\
\text { ffrate } \\
\text { outputgap } \\
\text { inf } \\
\mathrm{er} \\
\mathrm{mp} \\
\text { liq } \\
\text { gbl }
\end{array}\right)
$$

In this scenario, there is no contemporaneous feedback from monetary policy to bank lending, although monetary policy changes do affect bank liquidity. This enables a quantification of the indirect pass through of monetary policy shocks to bank lending through liquidity shocks, and comparison to the benchmark case where both monetary policy and liquidity shocks affect bank lending simultaneously.

\section{Results}

All series other than interest rates (federal funds rate and call money rate) are in natural logarithm with a base period of 1993-94. In each equation of the VAR model, a full set of 
monthly dummies is included to address deterministic seasonality. We also include a dummy for the Asian financial crisis in 1997 (taking values of 1 from July 1997 to January 1998, and 0 otherwise) and the global financial crisis (taking values of 1 from August 2007 to August 2011, and 0 otherwise). The VAR models are estimated using Iterated Seemingly Unrelated Regression (ISUR). The standard errors for impulse responses and forecast error variance decompositions are obtained by bootstrapping.

The results of various unit root tests indicate that all variables other than output gap contain a unit root. ${ }^{32}$ Therefore, we use the first difference of the variables. The variables entering into the estimation are: commodity price inflation; change in the federal fund rate; domestic (or WPI) inflation; output gap; (appreciation/depreciation of the currency against the USD) exchange rate; change in CMR (as the proxy measure for monetary policy); liquidity growth; and growth of bank credit. The number of lags included in all the VAR models is six. ${ }^{33}$

\footnotetext{
${ }^{32}$ We performed Augmented Dicky Fuller (ADF), Phillips Perron (PP), Kwiatkowski Peter Schmidt and Shin (KPSS), Elliott Rothenberg and Stock (ERS) point optimal test, and NG and Perron (Ng-Perron) modified unit root tests for the presence of unit roots in the series. If three or more tests suggested the presence of unit root in a series, we have taken the series to contain a unit root. These results are provided in Appendix, Table A2.

${ }^{33}$ Several approaches are adopted to arrive at an optimal lag length of six. First, we adopt a 'general to specific' approach and, given the monthly frequency of data, we start with lag length of 12 . The LM test for autocorrelation in the VAR residuals is performed at each lag length, and if residuals are found to be autocorrelated at that number of lags, the number of lags is increased (or decreased) to remove autocorrelation in the residuals. With this procedure, we arrive at the lag length of six. Further, we compute several lag length selection statistics, namely, Final Prediction Error (FPE), Akaike's Information Criterion (AIC), Schwarz's Bayesian Information Criterion (SBIC) and Hannan and Quinn Information Criterion (HQIC). Out of these statistics, Final Prediction Error (FPE) statistics select lag length of six while others suggest lag length of one. We still use the lag length of six, based mainly on two reasons: first, due to no autocorrelation in residuals at six lag length; and second, at lag length of six, the responses of three key macroeconomic variables (output gap,
} 
As a first step, we use the model to extract monetary policy shocks, and the residuals of the 'monetary policy instrument' (or CMR) equation are the estimates of monetary policy shocks. We find that the impulse responses of the three key macroeconomic variables (output gap, inflation and exchange rate) to one standard deviation positive interest rate shock are in line with economic theory. There is an immediate fall in inflation and output gap and a rise in the exchange rate (or appreciation of the currency vis-à-vis the USD) following a positive interest rate shock. These responses to monetary policy shocks are in the direction suggested by theory, and thus can be considered a good approximation of reality (refer to Appendix figure A2).

Once we isolate monetary policy shocks that are a good approximation of reality, ${ }^{34}$ we analyse the effect of these shocks on bank liquidity and lending under the benchmark case and alternative scenario, as discussed above. In order to analyse the different scenarios, we compute contemporaneous structural coefficients, structural forecast error variance decompositions (SFEVDs) and structural impulse response functions (SIRFs).

inflation and exchange rate) to monetary policy shocks are in line with the broad predictions of most theoretical models. This is an important prerequisite for us to isolate monetary policy shocks using an identification structure that does not give rise to any empirical anomalies (see Mishra and Mishra, 2012) and can be used in subsequent simulation exercises.

\footnotetext{
${ }^{34}$ Estimated monetary policy shocks are plotted in Appendix figure A1.
} 


\subsection{Contemporaneous Structural Coefficients}

Table 1 reports the structural contemporaneous coefficients (estimated matrix $\mathrm{P}$ from equation 2) for the benchmark case. The last row of Table 1 presents the structural contemporaneous coefficients in ' $g b l$ ' for the alternative case (estimated matrix $\mathrm{P}$ from equation 3). We report the structural coefficients only for ' $g b l$ ' equation in the alternative case, as only the ' $g b l$ ' equation changes from the benchmark case to alternative case. We find that monetary policy shocks (as identified by CMR) have a significant contemporaneous negative impact on bank lending. This suggests bank lending is sensitive to monetary policy changes and the pass-through of monetary policy change to bank lending is almost instantaneous. However, liquidity changes do not have an immediate effect on bank lending as suggested by the insignificant contemporaneous coefficient of 'liquidity' in bank lending equation. This does not change for the alternative case, where monetary policy shocks are restricted and do not have a contemporaneous effect on bank lending. We further notice that although monetary policy shocks have an effect on bank lending almost immediately, the same is not true for liquidity as the contemporaneous coefficient of ' $m p$ ' is insignificant in the 'liquidity' equation. The other notable result is the significant contemporaneous coefficients of global inflation (measured by international commodity price index) and international interest rate changes (measured by changes in federal fund rate) in monetary policy ' $m p$ ' equation. This supports our assumption that these two international variables act as a constraint on the setting of domestic monetary policy and enter into RBI's information set before it sets the monetary policy instrument. 
Table 1: Estimated Structural Contemporaneous Coefficients

\begin{tabular}{|c|c|c|c|c|c|c|c|c|}
\hline & com & ffrate & $\begin{array}{c}\text { outputga } \\
p\end{array}$ & inf & $e r$ & $m p$ & liq & $g b l$ \\
\hline com & $\begin{array}{c}32.629 * * * \\
(1.69)\end{array}$ & 0 & 0 & 0 & 0 & 0 & 0 & 0 \\
\hline ffrate & $\begin{array}{l}-3.452 \\
(2.39)\end{array}$ & $\begin{array}{c}5.8 * * * \\
(0.30)\end{array}$ & 0 & 0 & 0 & 0 & 0 & 0 \\
\hline outputgap & $\begin{array}{l}0.068 \\
(2.40)\end{array}$ & $\begin{array}{l}0.773 * \\
(0.43)\end{array}$ & $\begin{array}{c}72.898 * * \\
* \\
(3.77)\end{array}$ & 0 & 0 & 0 & 0 & 0 \\
\hline $\inf$ & $\begin{array}{c}-7.986 * * * \\
(2.43)\end{array}$ & $\begin{array}{l}-0.119 \\
(0.43)\end{array}$ & $\begin{array}{l}-3.331 \\
(5.33)\end{array}$ & $\begin{array}{c}202.34 * * * \\
(10.46)\end{array}$ & 0 & 0 & 0 & 0 \\
\hline$e r$ & $\begin{array}{c}-6.295 * * \\
(2.49)\end{array}$ & $\begin{array}{l}0.649 \\
(0.44)\end{array}$ & $\begin{array}{l}-6.291 \\
(5.35)\end{array}$ & $\begin{array}{c}35.854 * * \\
(14.91)\end{array}$ & $\begin{array}{c}62.36 * * * \\
(3.23)\end{array}$ & 0 & 0 & 0 \\
\hline$m p$ & $\begin{array}{c}5.508 * * \\
(2.53)\end{array}$ & $\begin{array}{c}-0.791 * \\
(0.44)\end{array}$ & $\begin{array}{c}-17.4^{* * *} \\
(5.43)\end{array}$ & $\begin{array}{c}-24.364 * \\
(15.08)\end{array}$ & $\begin{array}{l}-2.276 \\
(4.56)\end{array}$ & $\begin{array}{c}0.629 * * * \\
(0.03)\end{array}$ & 0 & 0 \\
\hline liq & $\begin{array}{l}-2.117 \\
(2.55)\end{array}$ & $\begin{array}{l}0.298 \\
(0.44)\end{array}$ & $\begin{array}{l}-6.844 \\
(5.52)\end{array}$ & $\begin{array}{l}-5.757 \\
(15.14)\end{array}$ & $\begin{array}{l}-3.971 \\
(4.57)\end{array}$ & $\begin{array}{l}-0.055 \\
(0.05)\end{array}$ & $\begin{array}{c}4.034 * * * \\
(0.21)\end{array}$ & 0 \\
\hline $\begin{array}{l}\text { gbl } \\
\text { (benchmark } \\
\text { case) }\end{array}$ & $\begin{array}{c}6.253^{* *} \\
(2.57)\end{array}$ & $\begin{array}{l}-0.277 \\
(0.44)\end{array}$ & $\begin{array}{l}5.205 \\
(5.53)\end{array}$ & $\begin{array}{l}-3.884 \\
(15.14)\end{array}$ & $\begin{array}{l}7.411^{*} \\
(4.59)\end{array}$ & $\begin{array}{c}-0.256^{* * *} \\
(0.05)\end{array}$ & $\begin{array}{l}-0.231 \\
(0.30)\end{array}$ & $\begin{array}{c}102.4 * * * \\
(5.30)\end{array}$ \\
\hline $\begin{array}{l}\text { gbl } \\
\text { (alternative } \\
\text { case) }\end{array}$ & $\begin{array}{c}7.929 * * * \\
(2.55)\end{array}$ & $\begin{array}{l}-0.563 \\
(0.44)\end{array}$ & $\begin{array}{l}-1.479 \\
(5.39)\end{array}$ & $\begin{array}{l}-12.547 \\
(15.05)\end{array}$ & $\begin{array}{l}6.142 \\
(4.58)\end{array}$ & $\begin{array}{l}0 \\
-\end{array}$ & $\begin{array}{c}-0.347 \\
0.29)\end{array}$ & $\begin{array}{c}94.91 * * * \\
(4.91)\end{array}$ \\
\hline
\end{tabular}

Notes:

(a) Figures in brackets are standard errors and $* * *, * *, *$ indicate significance at $1 \%, 5 \%$ and $10 \%$ respectively.

(b) com: International commodity price inflation (global inflation); ffrate: (change in) Federal funds rate; outputgap: Output gap; inf: WPI inflation; er: (change in) Nominal effective exchange rate; $m p$ : monetary policy instrument (which is CMR: Call money rate here); liq: liquidity growth; gbl: Growth of bank lending (or credit).

(c) $g b l$ (benchmark case): refer to equation 2.
(d) $g b l$ (alternative case): refer to equation 3. 


\subsection{Structural Forecast Error Variance Decompositions (SFEVDs)}

Table 2 reports the SFEVDs for benchmark case and alternative case of no contemporaneous feedback from monetary policy to bank lending. For the benchmark case, the results show that monetary policy shocks have a strong, immediate and persistent effect on bank lending. Monetary policy shocks explain roughly $12 \%$ variance in bank lending for the period 3 to 21 months. ${ }^{35}$ In contrast, liquidity shocks have a weak and insignificant initial effect on bank lending. A similar result is noted earlier in terms of the insignificant coefficient of 'liquidity' in the bank lending equation in the contemporaneous restriction matrix. However, the SFEVD results suggest that although the initial effect of liquidity shocks on bank lending is weak and insignificant, it gradually builds over time. The significant effect of liquidity shocks in explaining the variance of bank lending comes roughly with a lag of 9 months. The shocks to liquidity explain around $3.7 \%$ variance of bank lending at 9 months, which slowly increases to approximately $4.3 \%$ at 21 months.

The effect of monetary policy shocks on liquidity is rather small and comes with a lag. Monetary policy shocks have a significant effect on liquidity roughly at the 9 months lag and explain around $2.7 \%$ variance in liquidity of the banking sector. The effect of monetary policy shocks in explaining variance of liquidity marginally increases to $3 \%$ at the end of 21 months.

In an alternative case of no contemporaneous feedback from monetary policy to bank lending, the initial impact of monetary policy shocks on lending is weak (and insignificant) as

\footnotetext{
${ }^{35}$ We have reported SFEVDs for 21 months as beyond this period the SFEVDs become constant, suggesting that the effect of shock dies down somewhere between 21-24 months.
} 
expected. We notice that, in this hypothetical scenario, the significant effect of monetary policy on bank lending comes with a lag of 9 months. However, the effect of monetary policy shocks on bank lending is much smaller compared to the benchmark case, and these shocks explain around $2 \%$ variance of bank lending between the periods of 9 to 21 months. The noticeable result is the increase in the effect of liquidity shocks in explaining the variance of bank lending in comparison to the benchmark case. However, the significant effect of liquidity shocks on bank lending still comes with a lag of roughly 9 months. In this scenario, the shock to liquidity explains approximately $4 \%$ variance of bank lending at 9 months, which slowly increases to around 5\% at 21 months. The effect of monetary policy shocks on liquidity is also stronger in this scenario as compared to the benchmark case. Monetary policy shocks explain roughly $4 \%$ variance of liquidity between 6 to 21 months, while these shocks explain roughly $3 \%$ variance of liquidity for the same period in the benchmark identification. These results indicate the existence of an indirect feedback channel from monetary policy to bank lending working through bank liquidity. 
Table 2: Structural Forecast Error Variance Decompositions (SFEVDs) for Liquidity and Bank Lending

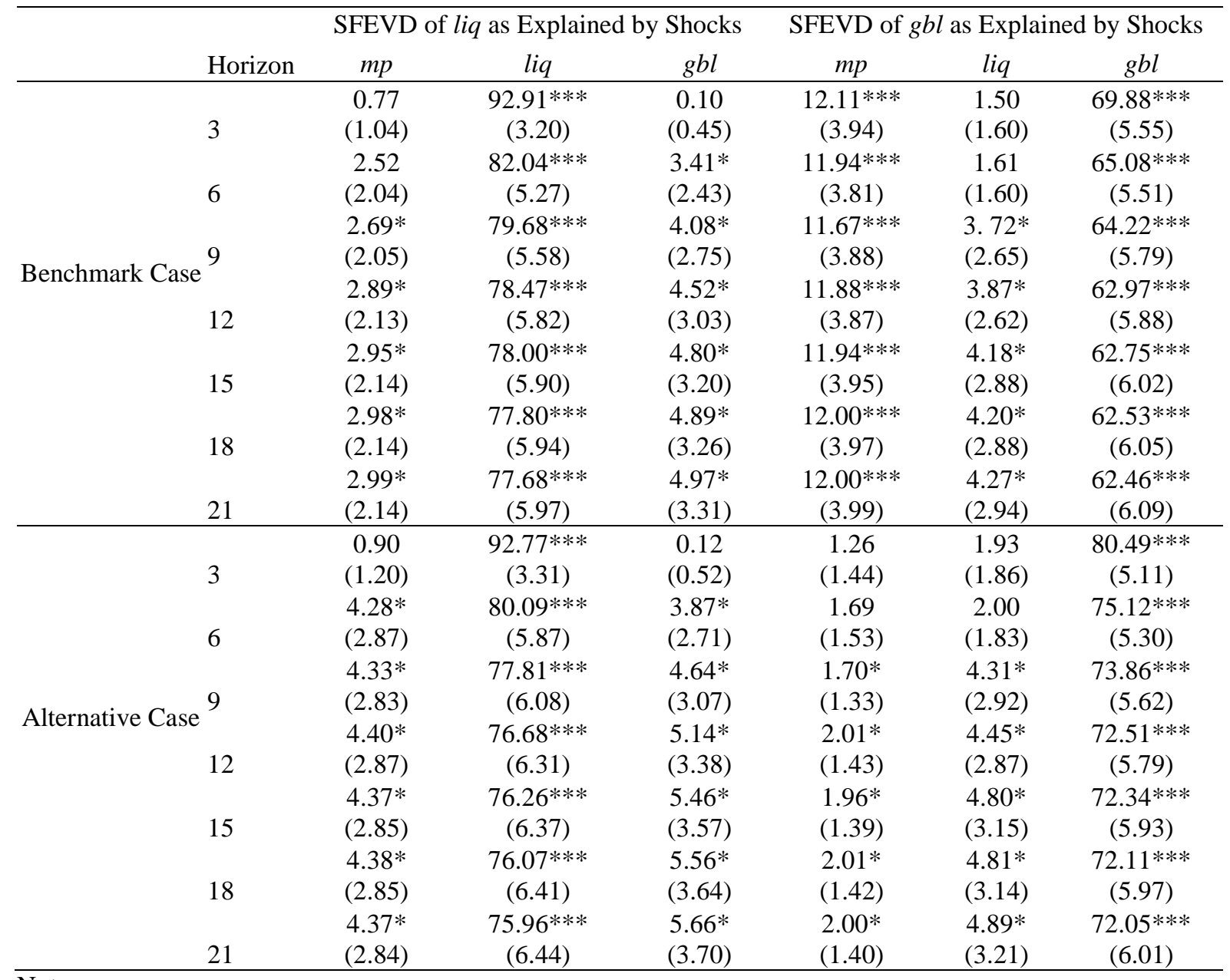

Notes:

(a) Figures in brackets are standard errors and $* * *, * * *$ indicate significance at $1 \%, 5 \%$ and $10 \%$ respectively.

(b) Alternative case is where there is no contemporaneous feedback from monetary policy to bank lending (refer to equation 3 and for benchmark case refer to equation 2).

(c) ' $m p$ ' refers to monetary policy instrument which is call money rate in our case; ' $g b l$ ' is growth of bank lending (or credit) and ' liq' is growth rate of liquidity index as constructed by the authors. 


\section{Discussion of Results}

The results of this paper are analysed through focussing on the following main themes:

- Analysing the impact and lag structure of monetary policy shocks and liquidity shocks on bank lending;

- Identifying the influence of other factors (namely, global inflation and interest rates, domestic output gap, inflation and exchange rate) on bank liquidity and lending behaviour;

- Examining the effect of monetary policy shocks on bank liquidity, and comparing the benchmark case with the alternative case (of no contemporaneous feedback from monetary policy to bank lending) for evidence of an indirect feedback channel of monetary policy to bank lending through bank liquidity.

As noted, the effect of monetary policy shocks on bank lending is immediate and strong. These shocks explain around 12\% variance of bank lending for the period of 3 to 21 months, while liquidity shocks explain around $4 \%$ variance of bank lending. Further, liquidity shocks operate with a lag, and their significant effect on bank lending comes with a lag of roughly 9 months.

Table 3 below reports the SFEVDs from the full model for bank lending and liquidity ${ }^{36}$. The Other factors that influence bank lending includes global variables, those being the global inflation rate (as measured by growth rate of international commodity prices) and federal

\footnotetext{
${ }^{36}$ The SFEVDs for all variables in the model are provided in Appendix Table A4. This table also contains a row 'consistent with theory', which suggest whether reported variance decompositions are in accordance with theory, or not.
} 
funds rate (as a proxy measure for the foreign interest rate). Together, these global variables explain roughly $11 \%$ variance in bank lending in a 6 to 18 month period. The susceptibility of bank lending to global factors is somewhat surprising as global exposure of Indian banks is rather limited. This sensitivity of bank lending to global variables can be attributed to an underlying fact, that is, the rising integration of the Indian economy with the global economy in the post reform period. The Financial Stability Report, the RBI (2010) noted that the rising integration of the domestic economy with the global economy creates a feedback loop between external shocks and domestic vulnerabilities, and the impact of external factors find its way into the financial sector from the real sector affected by these external shocks.

Gokarn \& Singh (2011) discuss the four channels that seem in operation through which global shocks are transmitted to the domestic economy. These channels are the trade, financial, commodity price and expectations channel. Empirically, they found that financial channels are becoming dominant in transmitting global shocks with rising capital account openness and capital flows. From a financial stability point of view, the uneven capital flows can put pressure on domestic asset prices and can cause huge capital losses to those entities which have exposure to such assets. This, in turn, can cause financial instability. The unfavourable effects of such volatile capital flows in India have so far been minimized through prudential sectoral exposure limits on bank lending risk weights and provisioning norms (for more details, refer to Gokarn \& Singh (2011)).

The other factor that affects bank lending significantly is domestic inflation. Shocks in domestic inflation explain between 4 and 6\% variance in bank lending over 3 to 18 months. Domestic inflation is an important variable for bank lending decisions as well as for private borrowing decisions, because it changes the real value of lending (or borrowing). Therefore, 
any unanticipated shock to inflation will either benefit the borrower if inflation is more than anticipated, or the lender if inflation is less than anticipated, and hence will affect bank lending.

Some of the recent studies in the literature found rising susceptibility of domestic inflation to external shocks as the Indian economy is becoming more globalized (for example Mishra \& Mishra (2012), Gokarn \& Singh (2011)). Gokarn \& Singh (2011) suggest that the pass through of external shocks to domestic prices can occur mainly through 'commodity prices' and 'exchange rate channels'. Mishra \& Mishra (2012) found that much of the volatility in domestic inflation can be explained through international commodity shocks ${ }^{37}$ and exchange rate shocks with these shocks explaining $11 \%$ and $13 \%$ volatility in domestic inflation, respectively. As noted earlier, with the rising susceptibility of bank lending to global factors, it seems that some of it finding its way into bank lending through domestic inflation.

Another macroeconomic variable that significantly affects both lending and liquidity of the banking sector is the exchange rate. As noted in Table 3, exchange rate shocks explain around 5\% and 3\% variance of bank liquidity and lending for the period 3 to 18 months, respectively. There are various channels through which the exchange rate can affect the balance sheet and hence lending by banks (Jonas, 2014). Notably, exchange rate fluctuations affect the lending activities of banks if exchange rate movements affect the cash flow of the borrowers, or banks themselves engage in cross-border lending denominated in foreign currency. The balance sheet exposure of commercial banks in India to foreign borrowing and lending is limited and has actually declined over the years. For example, the proportion of foreign liabilities to total liabilities for Indian commercial banks declined from $8 \%$ in 1999 to

\footnotetext{
${ }^{37}$ Mishra \& Mishra (2012) used crude oil prices as their measure of international commodity prices.
} 
2000 to $3 \%$ in 2012 to $2013 .^{38}$ The significant effect of exchange rate shocks in explaining variance in bank lending seems to occur from a rising linkage between the Indian economy and the global economy and, consequently, the availability of alternative funding sources for the corporate sector in the form of external commercial borrowings (ECB). As noted in the Financial Stability Report (RBI, 2010), this exposure of corporates, if unhedged, can expose them to foreign exchange risk and have an adverse impact on their domestic borrowings.

\footnotetext{
${ }^{38}$ These figures are based on the authors' calculation on the data sourced from Handbook of Statistics on the Indian economy (The RBI, 2013).
} 
Table 3: Structural Forecast Error Variance Decompositions (SFEVDs) for Liquidity and Bank Lending from Full Model

\begin{tabular}{|c|c|c|c|c|c|c|c|c|c|}
\hline & Horizon & com & ffrate & outputgap & inf & $e r$ & $m p$ & liq & $g b l$ \\
\hline \multirow{12}{*}{$\begin{array}{l}\text { Forecast error } \\
\text { variance of } \\
\text { 'liq' as } \\
\text { explained by } \\
\text { shocks }\end{array}$} & & 0.29 & 1.88 & 1.07 & 0.33 & $2.64 * *$ & 0.77 & $92.91 * * *$ & 0.10 \\
\hline & 3 & $(0.71)$ & (2.03) & (1.32) & $(0.90)$ & (1.56) & (1.04) & $(3.20)$ & $(0.45)$ \\
\hline & & 1.53 & 3.74 & 1.68 & 1.35 & $3.75^{*}$ & 2.52 & $82.04 * * *$ & $3.41 *$ \\
\hline & 6 & (1.80) & $(3.01)$ & (1.61) & (1.64) & $(2.34)$ & (2.04) & $(5.27)$ & $(2.43)$ \\
\hline & & 1.55 & 3.61 & 1.72 & 1.44 & $5.23 * *$ & $2.69 *$ & $79.68 * * *$ & $4.08 *$ \\
\hline & 9 & (1.70) & $(2.96)$ & (1.60) & (1.57) & (3.10) & $(2.05)$ & $(5.58)$ & $(2.75)$ \\
\hline & & 1.80 & $3.74 *$ & 1.94 & 1.49 & $5.17 * *$ & $2.89 *$ & $78.47 * * *$ & $4.52 *$ \\
\hline & 12 & (1.73) & $(2.96)$ & $(1.71)$ & $(1.55)$ & (3.03) & (2.13) & $(5.82)$ & (3.03) \\
\hline & & 1.80 & $3.72 *$ & 1.94 & 1.53 & $5.26^{* *}$ & $2.95^{*}$ & $78.00 * * *$ & $4.80 *$ \\
\hline & 15 & (1.72) & (2.94) & (1.70) & $(1.55)$ & (3.08) & (2.14) & $(5.90)$ & $(3.20)$ \\
\hline & & 1.82 & $3.73^{*}$ & 1.97 & 1.55 & $5.25 * *$ & $2.98 *$ & $77.80 * * *$ & $4.89 *$ \\
\hline & 18 & $(1.73)$ & $(2.92)$ & (1.72) & $(1.55)$ & $(3.07)$ & (2.14) & (5.94) & (3.26) \\
\hline \multirow{12}{*}{$\begin{array}{l}\text { Forecast error } \\
\text { variance of } \\
\text { 'gbl' as } \\
\text { explained by } \\
\text { shocks }\end{array}$} & & $6.83 * *$ & 2.66 & 0.06 & $4.20 *$ & 2.76 & $12.11 * * *$ & 1.50 & $69.88 * * *$ \\
\hline & 3 & $(3.55)$ & $(2.25)$ & $(0.31)$ & $(2.71)$ & $(2.20)$ & (3.94) & (1.60) & $(5.55)$ \\
\hline & & $8.12 * * *$ & $3.31 *$ & 1.32 & $5.55 * *$ & $3.08 *$ & $11.94 * * *$ & 1.61 & $65.08 * * *$ \\
\hline & 6 & (3.71) & $(2.33)$ & (1.36) & $(2.92)$ & $(2.25)$ & (3.81) & (1.60) & $(5.51)$ \\
\hline & & $7.32 * *$ & $3.45^{*}$ & 1.11 & $5.23 * *$ & $3.29 *$ & $11.67 * * *$ & $3.72 *$ & $64.22 * * *$ \\
\hline & 9 & $(3.39)$ & $(2.23)$ & (1.14) & $(2.71)$ & $(2.31)$ & $(3.88)$ & $(2.65)$ & (5.79) \\
\hline & & $7.55 * * *$ & $3.53 *$ & 1.24 & $5.63 * *$ & $3.33^{*}$ & $11.88 * * *$ & $3.87 *$ & $62.97 * * *$ \\
\hline & 12 & (3.38) & $(2.27)$ & (1.30) & $(2.87)$ & $(2.28)$ & $(3.87)$ & $(2.62)$ & (5.88) \\
\hline & & $7.41 * * *$ & $3.58 *$ & 1.22 & $5.54 * *$ & $3.37 *$ & $11.94 * * *$ & $4.18^{*}$ & $62.75 * * *$ \\
\hline & 15 & (3.36) & $(2.27)$ & (1.25) & $(2.85)$ & $(2.32)$ & $(3.95)$ & $(2.88)$ & $(6.02)$ \\
\hline & & $7.45 * * *$ & $3.56^{*}$ & 1.28 & $5.63 * *$ & $3.37 *$ & $12.00 * * *$ & $4.20 *$ & $62.53 * * *$ \\
\hline & 18 & $(3.37)$ & $(2.26)$ & (1.31) & $(2.90)$ & $(2.32)$ & (3.97) & (2.88) & $(6.05)$ \\
\hline
\end{tabular}

Notes:

(a) Figures in brackets are standard errors and ***,*** indicate significance at $1 \%, 5 \%$ and $10 \%$ respectively (b) com: International commodity price inflation (global inflation); ffrate: (Change in) Federal funds rate; outputgap: Output gap; inf: WPI inflation; neer: (Change in) Nominal effective exchange rate; mp: monetary policy instrument (which is CMR: Call money rate here); liq: liquidity growth; $g b l$ : Growth of bank lending (or credit). 


\subsection{Indirect Feedback Channel From Monetary Policy to Bank Lending Through}

\section{Liquidity}

In this section, we compare the two cases (benchmark and alternative case of no contemporaneous feedback from monetary policy to bank lending), and attempt to ascertain and quantify the indirect pass through of monetary policy shocks to bank lending through changes in the liquidity. For this, we analyse the responsiveness of bank liquidity to monetary policy shocks and check whether this responsiveness increases in the alternative case. Then, we evaluate the responsiveness of bank lending to liquidity shocks in both cases. If, in the alternative case, liquidity is found to be more responsive to monetary policy shocks and bank lending is then found to be more responsive to liquidity shocks, this implies (keeping everything else constant) a greater effect of liquidity shocks on bank lending via increased sensitivity of liquidity to monetary policy shocks. This provides evidence in favour of the existence of indirect feedback channel from monetary policy to bank lending through liquidity.

In Figure 2, we compare the structural impulse response function (SIRFs) for the two cases. The decreased responsiveness of bank lending to monetary policy shocks arises in the alternative case. This is by construction, as we do not allow the monetary policy shocks to have a contemporaneous effect on bank lending. Noticeably, we find that liquidity of the banking sector is more responsive to monetary policy shocks and, in turn, that there is a marginal increase in the responsiveness of bank lending to negative liquidity shocks in the alternative case. The increased responsiveness of bank lending to negative liquidity shocks is most visible when there is a drop in bank lending following a negative liquidity shock at 
around 8 to 9 months in Figure 2. This drop is sharper for the alternative case as compared to the benchmark case. 
Figure 2: Comparison of Structural Impulse Response Functions ${ }^{39}$

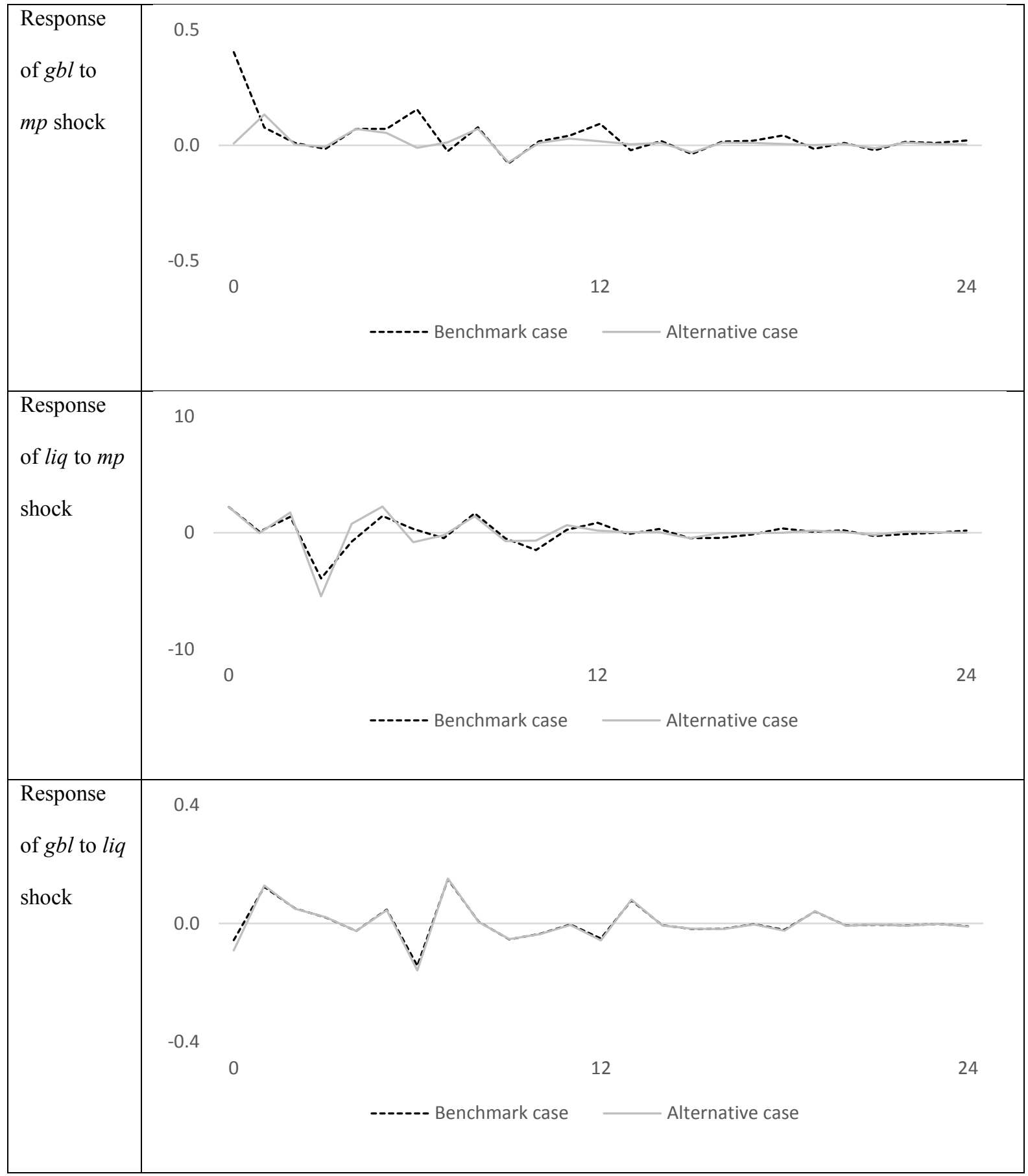

Notes:

(a) Alternative case is where there is no contemporaneous feedback from monetary policy to bank lending (refer to equation 3 in text and for benchmark case refer to equation 2).

${ }^{39}$ The confidence bands are not shown in this figure to show the differences in impulse responses between two scenarios clearly. The Figures with confidence bands for both the scenarios separately are provided in Appendix figures A3 and A4. 
The picture becomes clearer when we compare the SFEVDs in the two cases. In Table 4, we calculate the difference in SFEVDs of monetary policy shocks to liquidity and liquidity shocks to bank lending in the two cases. We find that in the alternative case of no feedback from monetary policy to bank lending, shocks to monetary policy explain around 1 to $2 \%$ more variance in bank liquidity, and that liquidity shocks explain 0.4 to $0.6 \%$ more variance of bank lending for the period 3 to 21 months. These results indicate the presence of indirect feedback of monetary policy to bank lending through liquidity for Indian commercial banks. For any change in liquidity due to monetary policy shocks, around $33 \%(0.5 / 0.6$ as a\% of 1.5/1.6) of it will transfer to the lending activities.

Table 4: Testing of Differences in SFEVDs in Alternative and Benchmark Case

\begin{tabular}{lcc}
\hline & SFEVD of liq as Explained by Shocks to $m p$ & SFEVD of $g b l$ as Explained by Shocks to liq \\
\hline Horizon & (alternative case -benchmark case) & (alternative case -benchmark case) \\
3 & 0.13 & $0.43^{* *}$ \\
& $(0.11)$ & $(0.18)$ \\
6 & $1.77^{* * *}$ & $0.40^{* *}$ \\
& $(0.25)$ & $(0.18)$ \\
9 & $1.64^{* * *}$ & $0.59^{* *}$ \\
& $(0.25)$ & $(0.28)$ \\
12 & $1.51^{* * *}$ & $0.58^{* *}$ \\
& $(0.26)$ & $(0.28)$ \\
15 & $1.42^{* * *}$ & $0.62^{* *}$ \\
& $(0.26)$ & $(0.31)$ \\
18 & $1.40^{* * *}$ & $0.62^{* *}$ \\
& $(0.26)$ & $(0.31)$ \\
21 & $1.38^{* * *}$ & $0.62 * *$ \\
\hline Notes* & $(0.26)$ & $(0.31)$
\end{tabular}

Notes:
(a) Figures in brackets are standard errors and $* * *, * *, *$ indicate significance at $1 \%, 5 \%$ and $10 \%$ respectively.

(b) Alternative case is where there is no contemporaneous feedback from monetary policy to bank lending (refer to equation 3 and for benchmark case refer to equation 2).

(c) ' $m p$ ' refers to monetary policy instrument which is call money rate in our case; ' $g b l$ ' is growth of bank lending (or credit) and ' $l i q$ ' is growth rate of liquidity index as constructed by the authors. 


\section{Conclusions}

In this study, we build a liquidity index for commercial banks in India using factor analysis. Using this index in a structural VAR framework, we build a short run model of monetary policy for India. The identification scheme used in this study to extract monetary policy shocks produces these shocks without any empirical anomalies. Therefore, the model is considered a good approximation of reality to conduct experiments to evaluate the interaction among three variables of interest: monetary policy, liquidity, and lending behaviour of the banking sector.

We find that monetary policy shocks have strong initial and persistent impacts on bank lending, while the significant effect of liquidity shocks on bank lending comes with a lag of roughly 9 months. We also find evidence in favour of an indirect feedback channel between monetary policy and bank lending that operates through changes in bank liquidity. We find that the pass through of liquidity changes (due to monetary policy shocks) to bank lending is roughly $33 \%$, implying that around $33 \%$ of a liquidity change that follows a monetary policy shock is passed on to bank lending activities. However, this indirect effect of monetary policy on bank lending (through liquidity) operates with a lag of roughly 6 to 9 months.

The proposed methodology to examine indirect feedback channel between monetary policy shocks and bank lending operating through liquidity changes has wider applicability. By suitably modifying the VAR contemporaneous restriction matrix based on the structure of other economies and reaction functions of their central banks, the suggested approach can be used to analyse the pass through of liquidity changes due to monetary policy shock to bank lending in other economies. 


\section{Appendix: Methodology/Description}

\section{Methodology of Construction of Liquidity Index}

We perform factor analysis on the observable variables, namely, liquid assets to total assets, cash in hand to demand deposits, liquid assets to demand deposits, and liquid assets to total deposits, using principal component factoring. Principal component factoring is a method of factor extraction where linear combinations of the observable variables are formed. This allows us to extract and select the initial factors. The number of factors is equivalent to the number of latent variables, and each factor is a weighted combination of the input variables. We use two objective criteria to decide on the number of factors to be retained. First, we use Kaiser criteria, which retain factors with reported eigenvalues that are greater than one. The eigenvalue is the total variance explained by each factor. Factors with eigenvalues of less than one are disregarded because they do not have enough total variance explained to represent unique factors. Second, we retain factors with a cumulative variance greater than 95 per cent (Hair et al., 1995; Williams et al., 2012). Cumulative variance is simply the amount of variance explained by that number of factors (Refer to Table A1).

To more clearly identify the relevance of each variable to each factor, the factor loads are rotated using orthogonal varimax methodology. The purpose of rotation is to simplify the structure of the analysis. Orthogonal varimax methodology is used for two reasons. First, varimax is the most common methodology for rotating the factor matrix because it minimises the number of variables that have high loadings on each factor. Varimax does this by 
maximising the squared loading variance summed across the factors. ${ }^{40}$ Second, the orthogonal methodology is most suitable where there is more than one factor and factors are independent. ${ }^{41}$ Using the aforementioned strategy, we identify two factors to be retained. These two factors together explain more than 99 per cent variance of the data. Once the number of factors is identified, the predicted factor scores (i.e. the factor scores for each observation) are estimated using regression analysis. ${ }^{42}$ The predicted factors are weighted according to the percentage of cumulative variance explained by each of the two factors, and a non-standardised liquidity index (NSLI) is calculated for each observation by applying the methodology proposed by Krishan (2010) in the following way:

$$
N S L I_{t}=\omega^{F 1} s_{t}^{F 1}+\omega^{F 2} s_{t}^{F 2}
$$

Where $\omega^{F i}$ is the weight of factor $i$, and $s_{t}^{F i}$ is the factor score of factor $i$ at time $t$, and $i$ is the total number of factors, which in our case is $2 .^{43}$

From the non-standardised liquidity index (NSLI), a standardised liquidity index (SLI) ${ }^{44}$ is calculated as:

$$
S L I_{t}=\frac{N S L I_{t}-M i n N S L I}{M a x N S L I-M i n N S L I} \times 100
$$

\footnotetext{
${ }^{40}$ This is preferred to the quartimax approach, which maximises the squared loading variance across factors (that is, summed over the variables).

${ }^{41}$ Another benefit of using orthogonal methodology is that the loadings represent the correlations.

${ }^{42}$ STATA was used to carry out this procedure. To compute the factor scores for each given observation, STATA multiplies the standardised score on each factor by the corresponding factor loading.

${ }^{43}$ The weights are calculated as $\%$ variance explained by factor ' $i{ }^{\prime} / \%$ variance explained by $($ factor $1+$ factor 2$)$
}

${ }^{44}$ Standardisation of the index eliminates positive and negative values, and makes the index easier to interpret. 


\section{Note on Estimated Monetary Policy Shocks}

The graph below (Figure A1) shows that the period of late 1997 was characterized by the loose monetary policy (or expansionary monetary policy) and this is what we observed historically also that the period of late 1996 to late 1997 was characterized by excess liquidity in the economy mainly due to the reduction in Cash Reserve Ratio ${ }^{45}$, Reserve bank's intervention in the forex market in the form of dollar purchase, upsurge in bank deposits and sluggish growth in non-food credit.

However, due to the continuing volatility in the foreign exchange market in the wake of South- East Asian Crisis, the Reserve Bank undertook a series of policy measures in early 1998 to control liquidity and ease the pressure on the foreign exchange market. As a result, fortnightly average call money rate reached a historical high of $50 \%$ in the fortnight ended at January 30, 1998. This historical fact is supported by the estimated shocks from our model where we see a spike exactly in the same month.

In period from 1999 to 2000, Indian economy faced challenges on several fronts. On the one hand, there was acceleration in global output and trade due to the continuing strength of the U.S economy and sharp recovery of the Asian economy, but on the other hand the gains from global economic recovery was eroded by more than doubling of oil prices due to production curbs by OPEC. For oil importing country like India, this oil price surge translated

\footnotetext{
45 "Consistent with the medium term objectives and on a review of the monetary and credit situation, CRR to be maintained by Scheduled Commercial Banks (excluding Regional Rural Banks) was reduced by 2 percentage points from $12 \%$ of their net demand and time liabilities to $10 \%$ in 4 phases of $0.5 \%$ point each, effective from the fortnights beginning October 26, 1996, November 9, 1996, January 4, 1997 and January 18, 1997 respectively. Each percentage point reduction of CRR increased the lendable resources of banks by about Rs. 4,275 crore." (Chapter V, pp. V-21, Report on Currency and Finance, the RBI (1996-97)).
} 
into inflationary pressure and constriction of import purchasing power. Thus on one side the inflation was rising due to rise in international oil prices and on the other side 'the lack of sufficient demand pull characterizing the phase of business cycle through which the domestic economy was transiting, restrained the impulses for accelerating growth'(Chapter 1, pp. I1,Report on Currency and Finance, the RBI (1999-2000)). During this period the monetary policy remained mainly tight due to inflation considerations and also the sporadic volatility of foreign exchange market. This is also indicated by estimated shocks.

The period of 2002-03 to 2003-04 was characterized by ample liquidity in the economy due to sustained accretions of capital inflows, contraction in food credit and liquidity overhang (Chapter II, Report on Currency and Finance, the RBI (2003-04)). The monetary policy was mainly loose and this is reflected in the figure.

From late 2004 to early 2006, Indian economy, on one hand, remained upbeat on GDP growth mainly because of pick-up in agriculture output. On the other side, high international crude oil prices put upward pressure on inflation. Indian economy continued to exhibit strong growth in 2006-07 as well along with elevated inflation level driven mainly by primary food articles and manufactured products. The Annual Policy Statement of the RBI recognized the danger of overheating because of the combination of high growth and inflation along with rising asset prices and tightening infrastructural bottlenecks and set the direction of monetary policy setting. In view of the underlying inflationary pressure, the RBI mainly pursued a tight monetary policy during late 2004 to early 2007. The RBI took several pre-emptive measures as increase in CRR and repo and reverse repo rate, to keep inflationary expectations well anchored (Chapter II, Report on Currency and Finance, the RBI (2005-06 \& 2006-07)). This 
tightening stance of monetary policy can also be observed in our estimated shocks for this period.

The RBI switched to an expansionary monetary policy regime from late 2008 till early 2010 because of the deepening effect of Global Financial crisis on Indian and receding inflationary pressures (Chapter V, Report on Currency and Finance, the RBI (2009-10)) ${ }^{46}$. This switch in monetary policy stance is also reflected in our estimated shocks.

\section{Vector Autoregression (VAR) / Structural Vector Autoregression (SVAR) Models}

A VAR is a convenient device to summarise first and second order moment properties of the data. The basic problem with the VAR is that a given set of second moments is consistent with many such dynamic response functions. Solving this problem amounts to making explicit assumptions that justify focusing on a particular dynamic response function. A VAR for a k-dimensional vector of variables $Y_{t}$, is given by:

$$
Y_{t}=A_{1} Y_{(t-1)}+A_{2} Y_{(t-2)}+\cdots \ldots \ldots \ldots \ldots \ldots A_{p} Y_{(t-p)}+\mu_{t}, E \mu_{t} \mu_{t}^{\prime}=\Sigma
$$

Here, $p$ is a nonnegative integer and $\mu_{t}$ is uncorrelated with all variables dated $(t-1)$ and earlier. Knowing $A_{i}{ }^{\prime} s$, the $\mu_{t}{ }^{\prime} s$ and $\Sigma$ are insufficient to compute the dynamic response function of $Y_{t}$ to the fundamental economic shock in the economy. The basic reason is that $\mu_{\mathrm{t}}$ is the one step ahead forecast error in $Y_{t}$. Each element of $\mu_{t}$ reflects the effect of all the fundamental economic shocks. There is no reason to presume that any element of $\mu_{t}$ corresponds to a particular economic shock, for example, a monetary policy shock.

\footnotetext{
${ }^{46}$ For detailed analysis of real sector, price situation and related monetary measures refer to Annual series of Report on Currency and Finance, the RBI Publication.
} 
This shortcoming is overcome by rewriting (4) in terms of mutually uncorrelated innovations. Suppose we have a matrix $P$ such that $\Sigma=P P^{\prime}$. If we had such a $\mathrm{P}$, then $P^{-1} \Sigma P^{\prime-1}=I_{k}$. This implies that $P$ can be used to orthogonalise $\mu_{t}$. Choosing $P$ is similar to placing identification restrictions on the system of dynamic simultaneous equations. Sims (1980) popularised the method of choosing $P$ to be the Cholesky decomposition of $\Sigma$. The impulse response functions based on this choice of $P$ are known as the orthogonalised impulse response functions. Choosing $P$ to be the Cholesky decomposition of $\Sigma$ is equivalent to imposing a recursive structure for the corresponding dynamic structural equation model.

An alternative to the recursive VAR or temporal ordering of variables is to allow for a more elaborate set of restrictions guided by economic theory. This is referred to as a structural VAR (SVAR). The SVAR approach integrates the need to identify the causal impulse response functions into the model specification and estimation process. Sufficient identification restrictions can be obtained by placing either short run or long run restrictions on the model. In this exercise we make use of the structural vector autoregression with short run restrictions. ${ }^{47}$ The short run SVAR model can be written as:

$$
A\left(I_{k}-A_{1} L-A_{2} L^{2} \ldots \ldots \ldots \ldots \ldots \ldots \ldots-A_{p} L^{p}\right) y_{t}=A \epsilon_{t}=B e_{t}
$$

Here, $L$ is the lag operator, $A, B$ and $A_{i}, i=1, \ldots \ldots \ldots, p$ are $K X K$ matrices of parameters, $\epsilon_{t}$ is a $K X 1$ vector of innovations with $\epsilon_{t} \sim N(0, \Sigma)$ and $E\left(\epsilon_{t}, \epsilon_{t}^{\prime}\right)=0_{k}$ for all $s \neq t$ and $e_{t}$ is a $K X 1$ vector of orthogonalised disturbances, that is, $e_{t} \sim N\left(0, \mathrm{I}_{k}\right)$ and $E\left(e_{t}, e_{t}^{\prime}\right)=0_{k}$ for

\footnotetext{
${ }^{47}$ We place only short run restrictions to identify monetary policy shocks. We do not go into the long run restrictions structure. As we limit ourselves to short run (that is, the period up to two year), we do not consider issues related to cointegration, which refers to the existence of long run equilibrium.
} 
all $s \neq t$. These transformations of the innovations allow us to analyse the dynamics of the system in terms of a change to an element of $e_{t}$.

The short run SVAR model chooses $P=A^{-1} B$ ( $A$ and $B$ are assumed to be nonsingular) to identify causal impulse response functions. P defines a transformation of $\Sigma$ that identifies the structural impulse response functions. To see this point, note that the latter equality in equation (5) implies that:

$$
A \epsilon_{t} \epsilon_{t}^{\prime} A^{\prime}=B e_{t} e_{t}^{\prime} B^{\prime}
$$

Taking the expectation of both sides yields:

$$
\Sigma=P P^{\prime}
$$

Since, $\Sigma$ contains $K X(K+1) / 2$ free parameters, we need $K X(K+1) / 2$ restrictions. In SVAR modelling, $P$ identifies the structural impulse response functions and $P$ itself is identified by the restrictions placed on the parameters in $A$ and $B$. Since there are $2 K^{2}$ total parameters in $A$ and $B$, the order condition for identification requires that there must be at least $2 K^{2}-K(K+1) / 2$ restrictions placed on those parameters. In VAR modelling, $A$ is a lower triangular matrix with ones on the diagonal and $B$ is diagonal matrix, $P$ (obtained by plugging in estimates $A$ and $B$ ) and should be equal to Cholesky decomposition of $\Sigma$. However, in the structural VAR approach, $P$ can be any structure as long as it has enough restrictions. 


\section{Appendix: Tables}

Table A1: Factor Analysis Results

\begin{tabular}{|c|c|c|c|}
\hline \multicolumn{4}{|c|}{ Factor Selection Statistics } \\
\hline & Eigenvalue & Cumulative variance & Weights \\
\hline Factor1 & 2.92 & 0.73 & 0.73 \\
\hline Factor 2 & 1.04 & 0.99 & 0.27 \\
\hline \multicolumn{4}{|c|}{ Factor Loadings* } \\
\hline Variables & Factor 1 & Factor 2 & Uniqueness \\
\hline $\begin{array}{l}\text { Liquid assets to total } \\
\text { assets }\end{array}$ & 0.996 & - & 0.005 \\
\hline $\begin{array}{l}\text { Cash in hand to demand } \\
\text { deposits }\end{array}$ & - & 0.998 & 0.002 \\
\hline $\begin{array}{l}\text { Liquid assets to demand } \\
\text { deposits }\end{array}$ & 0.957 & - & 0.021 \\
\hline $\begin{array}{l}\text { Liquid assets to total } \\
\text { deposits }\end{array}$ & 0.996 & - & 0.008 \\
\hline \multicolumn{4}{|c|}{ Predicted Factor Scores } \\
\hline Variables & Factor 1 & Factor2 & \\
\hline $\begin{array}{l}\text { Liquid assets to total } \\
\text { assets }\end{array}$ & 0.35 & -0.12 & - \\
\hline $\begin{array}{l}\text { Cash in hand to demand } \\
\text { deposits }\end{array}$ & -0.05 & 0.95 & \\
\hline $\begin{array}{l}\text { Liquid assets to demand } \\
\text { deposits }\end{array}$ & 0.32 & 0.18 & - \\
\hline $\begin{array}{l}\text { Liquid assets to total } \\
\text { deposits }\end{array}$ & 0.35 & -0.09 & - \\
\hline \multicolumn{4}{|c|}{ Correlation between Factors and Standardised Liquidity Index } \\
\hline Factor1 & 0.94 & & \\
\hline Factor2 & 0.34 & & \\
\hline
\end{tabular}


Table A2: Results for unit root tests

\begin{tabular}{|c|c|c|c|c|c|}
\hline Variable & ADF Test & PP Test & KPSS Test & $\begin{array}{l}\text { ERS Point } \\
\text { Optimal } \\
\text { Test }\end{array}$ & $\begin{array}{l}\text { Ng-Perron } \\
\text { Modified } \\
\text { Unit root } \\
\text { Test } \\
\end{array}$ \\
\hline com & -0.57 & -0.59 & $1.39 * * *$ & 15.95 & -0.86 \\
\hline ffrate & -1.66 & -1.22 & $0.91 * * *$ & 9.78 & -2.79 \\
\hline outputgap & $-4.84 * * *$ & $-4.09 * * *$ & 0.01 & 42.55 & 0.30 \\
\hline inf & 0.84 & 1.20 & $1.69 * * *$ & 808.06 & 2.01 \\
\hline er & $-2.16^{* *}$ & -1.88 & 0.12 & $2.90 * *$ & $-11.48 * *$ \\
\hline$m p$ & $-7.21 * * *$ & $-7.58 * * *$ & 0.33 & $0.46 * * *$ & $-56.93 * * *$ \\
\hline$l i q$ & $-3.12 * *$ & $-2.81 *$ & $0.43^{*}$ & 4.66 & $-6.36^{*}$ \\
\hline$g b l$ & -0.57 & 0.49 & $1.71 * * *$ & 2045.06 & $-13.08 * *$ \\
\hline \multicolumn{6}{|c|}{ After First Differencing } \\
\hline$\Delta c o m$ & $-10.37 * * *$ & $-10.46^{* * *}$ & 0.15 & $0.28 * * *$ & $-87.82 * * *$ \\
\hline$\Delta f f r a t e$ & $-4.14 * * *$ & $-11.75^{* * *}$ & 0.07 & $1.02 * * *$ & $-23.81 * * *$ \\
\hline \multicolumn{6}{|l|}{ soutputgap } \\
\hline$\Delta i n f$ & $-9.37 * * *$ & $-9.36 * * *$ & 0.22 & $0.54 * * *$ & $-59.21 * * *$ \\
\hline$\Delta e r$ & $-10.01 * * *$ & $-11.87 * * *$ & 0.14 & $0.36 * * *$ & $-86.41 * * *$ \\
\hline \multicolumn{6}{|l|}{$\Delta m p$} \\
\hline$\Delta l i q$ & $-12.70 * * *$ & $-18.75^{* * *}$ & 0.21 & $1.11 * * *$ & -1.15 \\
\hline$\Delta g b l$ & $-2.74 *$ & $-15.29 * * *$ & 0.21 & 14.47 & -0.67 \\
\hline
\end{tabular}

Notes:
(a) For the ADF test the lag length was selected by using SIC (Modified SIC for ERS \& Ng-Perron) values.

(b.) For PP and KPSS test the optimal bandwidth was selected by Newey-West method using Bartlett kernel.

(c) All the unit root tests were performed with the assumption of constant term in the logarithm of the series, with the null hypothesis of unit root for all tests except for KPSS test where null was stationarity.

(d) The maximum lag length selected in all cases is 14 based on the formula lag length $\left.\max _{1}=\operatorname{int}_{(12}(\mathrm{T} / 100)^{0.25}\right)$ suggested by Hayashi (2000, p.594).

(e) The spectral estimation method for the ERS point optimal test and Ng-Perron modified unit root test is AR spectral OLS and AR GLS (detrended), respectively.

(f) ${ }^{*},{ }^{* *},{ }^{* * *}$ denote statistical significance at the $10 \%, 5 \%$ and $1 \%$ levels respectively. 
Table A3: Results of Pair-wise Granger Causality Test

\begin{tabular}{lcc}
\hline Null Hypothesis & F-Statistic & Prob. \\
\hline outputgap does not Granger Cause inf & 2.46 & 0.00 \\
inf does not Granger Cause outputgap & 1.13 & 0.33 \\
inf does not Granger Cause er & 0.63 & 0.43 \\
er does not Granger Cause inf & 1.85 & 0.18 \\
outputgap does not Granger Cause er & 2.04 & 0.01 \\
er does not Granger Cause outputgap & 1.23 & 0.24 \\
\hline
\end{tabular}

Note: The lag length was selected by using the most common lag choice from alternative 5 criteria: LR, FPE, AIC, SIC and HQ test statistics. 
Table A4: Structural Forecast Error Variance Decompositions (SFEVDs) for full model

\begin{tabular}{|c|c|c|c|c|c|c|c|c|c|}
\hline & Horizon & com & ffrate & outputgap & $\inf$ & $e r$ & $m p$ & $l i q$ & $g b l$ \\
\hline \multirow{6}{*}{$\begin{array}{c}\text { Forecast error variance } \\
\text { of 'outputgap' as } \\
\text { explained by shocks }\end{array}$} & 3 & $\begin{array}{c}1.02 \\
(1.66)\end{array}$ & $\begin{array}{c}5.25 \\
(4.15)\end{array}$ & $\begin{array}{c}88.87 * * * \\
(4.83)\end{array}$ & $\begin{array}{c}0.35 \\
(0.69)\end{array}$ & $\begin{array}{c}0.21 \\
(0.55)\end{array}$ & $\begin{array}{l}2.67 * \\
(2.04)\end{array}$ & $\begin{array}{c}1.05 \\
(1.11)\end{array}$ & $\begin{array}{c}0.57 \\
(0.88)\end{array}$ \\
\hline & 6 & $\begin{array}{c}3.35 \\
(3.23)\end{array}$ & $\begin{array}{l}7.93 * \\
(5.17)\end{array}$ & $\begin{array}{c}73.96 * * * \\
(7.35)\end{array}$ & $\begin{array}{c}5.26 \\
(4.06)\end{array}$ & $\begin{array}{c}2.08 \\
(2.71)\end{array}$ & $\begin{array}{l}4.91 * \\
(2.99)\end{array}$ & $\begin{array}{c}2.05 \\
(1.80)\end{array}$ & $\begin{array}{c}0.47 \\
(0.65)\end{array}$ \\
\hline & 9 & $\begin{array}{c}4.12 \\
(3.44)\end{array}$ & $\begin{array}{l}8.80 * \\
(5.37)\end{array}$ & $\begin{array}{c}71.89 * * * \\
(7.84)\end{array}$ & $\begin{array}{l}5.03 * \\
(3.90)\end{array}$ & $\begin{array}{c}2.66 \\
(3.04)\end{array}$ & $\begin{array}{l}4.75^{*} \\
(3.08)\end{array}$ & $\begin{array}{c}2.02 \\
(1.77)\end{array}$ & $\begin{array}{c}0.74 \\
(0.85)\end{array}$ \\
\hline & 12 & $\begin{array}{l}4.65^{*} \\
(3.46)\end{array}$ & $\begin{array}{c}9.86^{* *} \\
(5.80)\end{array}$ & $\begin{array}{c}69.37 * * * \\
(8.65)\end{array}$ & $\begin{array}{l}5.55^{*} \\
(4.27)\end{array}$ & $\begin{array}{c}3.16 \\
(3.49)\end{array}$ & $\begin{array}{l}4.57 * \\
(2.91)\end{array}$ & $\begin{array}{c}2.00 \\
(1.64)\end{array}$ & $\begin{array}{c}0.83 \\
(0.82)\end{array}$ \\
\hline & 15 & $\begin{array}{l}4.62 * \\
(3.48)\end{array}$ & $\begin{array}{c}9.71 * * \\
(5.74)\end{array}$ & $\begin{array}{c}69.28 * * * \\
(8.75)\end{array}$ & $\begin{array}{l}5.58 * \\
(4.30)\end{array}$ & $\begin{array}{c}3.13 \\
(3.47)\end{array}$ & $\begin{array}{l}4.68 * \\
(2.95)\end{array}$ & $\begin{array}{c}2.14 \\
(1.73)\end{array}$ & $\begin{array}{c}0.84 \\
(0.81)\end{array}$ \\
\hline & 18 & $\begin{array}{l}4.84 * \\
(3.57)\end{array}$ & $\begin{array}{c}9.70 * * \\
(5.74)\end{array}$ & $\begin{array}{c}68.97 * * * \\
(8.86)\end{array}$ & $\begin{array}{l}5.68 * \\
(4.38)\end{array}$ & $\begin{array}{c}3.17 \\
(3.51)\end{array}$ & $\begin{array}{l}4.66^{*} \\
(2.94)\end{array}$ & $\begin{array}{c}2.13 \\
(1.72)\end{array}$ & $\begin{array}{c}0.85 \\
(0.81)\end{array}$ \\
\hline Consistent with theory & & Yes & Yes & Yes & Yes & No & Yes & No & No \\
\hline \multirow{6}{*}{$\begin{array}{l}\text { Forecast error variance } \\
\text { of 'inf' as explained by } \\
\text { shocks }\end{array}$} & 3 & $\begin{array}{c}10.55^{* *} \\
(4.76)\end{array}$ & $\begin{array}{c}1.66 \\
(2.02)\end{array}$ & $\begin{array}{c}1.78 \\
(1.62)\end{array}$ & $\begin{array}{c}82.47 * * * \\
(5.59)\end{array}$ & $\begin{array}{l}2.09 \\
(2.02)\end{array}$ & $\begin{array}{c}0.44 \\
(0.83)\end{array}$ & $\begin{array}{c}0.27 \\
(0.70)\end{array}$ & $\begin{array}{c}0.73 \\
(1.02)\end{array}$ \\
\hline & 6 & $\begin{array}{c}12.84 * * * \\
(5.06)\end{array}$ & $\begin{array}{c}3.25 \\
(2.56)\end{array}$ & $\begin{array}{l}4.08 * * \\
(2.31)\end{array}$ & $\begin{array}{c}67.28 * * * \\
(5.92)\end{array}$ & $\begin{array}{l}5.91 * * \\
(3.02)\end{array}$ & $\begin{array}{c}0.95 \\
(1.11)\end{array}$ & $\begin{array}{l}4.15 * * \\
(2.37)\end{array}$ & $\begin{array}{c}1.55 \\
(0.43)\end{array}$ \\
\hline & 9 & $\begin{array}{c}12.41 * * * \\
(4.89)\end{array}$ & $\begin{array}{c}4.86^{* *} \\
(2.69)\end{array}$ & $\begin{array}{c}5.88 * * * \\
(2.46)\end{array}$ & $\begin{array}{c}63.10 * * * \\
(5.82)\end{array}$ & $\begin{array}{c}6.44 * * \\
(2.97)\end{array}$ & $\begin{array}{c}1.24 \\
(1.14)\end{array}$ & $\begin{array}{c}4.59 * * \\
(2.50)\end{array}$ & $\begin{array}{c}1.49 \\
(1.38)\end{array}$ \\
\hline & 12 & $\begin{array}{c}12.35 * * * \\
(4.74)\end{array}$ & $\begin{array}{c}6.44 * * \\
(3.23)\end{array}$ & $\begin{array}{c}5.74 * * * \\
(2.39)\end{array}$ & $\begin{array}{c}61.35^{* * * *} \\
(5.91)\end{array}$ & $\begin{array}{l}6.53 * * \\
(2.92)\end{array}$ & $\begin{array}{l}1.52 * \\
(1.15)\end{array}$ & $\begin{array}{c}4.50 * * \\
(2.43)\end{array}$ & $\begin{array}{c}1.58 \\
(1.38)\end{array}$ \\
\hline & 15 & $\begin{array}{c}12.34 * * * \\
(4.71)\end{array}$ & $\begin{array}{c}6.78 * * \\
(3.41)\end{array}$ & $\begin{array}{c}5.79 * * * \\
(2.42)\end{array}$ & $\begin{array}{c}60.94 * * * \\
(5.97)\end{array}$ & $\begin{array}{l}6.55 * * \\
(2.90)\end{array}$ & $\begin{array}{l}1.53 * \\
(1.15)\end{array}$ & $\begin{array}{c}4.47 * * \\
(2.42)\end{array}$ & $\begin{array}{c}1.59 \\
(1.37)\end{array}$ \\
\hline & 18 & $\begin{array}{c}12.33 * * * \\
(4.69)\end{array}$ & $\begin{array}{c}6.82 * * \\
(3.45)\end{array}$ & $\begin{array}{c}5.87 * * * \\
(2.46)\end{array}$ & $\begin{array}{c}60.78 * * * \\
(5.99)\end{array}$ & $\begin{array}{c}6.53 * * \\
(2.89)\end{array}$ & $\begin{array}{l}1.57 * \\
(1.15)\end{array}$ & $\begin{array}{c}4.47 * * \\
(2.41)\end{array}$ & $\begin{array}{c}1.63 \\
(1.38)\end{array}$ \\
\hline Consistent with theory & & Yes & Yes & Yes & Yes & Yes & Yes & Yes & No \\
\hline \multirow{6}{*}{$\begin{array}{l}\text { Forecast error variance } \\
\text { of 'er' as explained by } \\
\text { shocks }\end{array}$} & 3 & $\begin{array}{c}3.24 \\
(2.79)\end{array}$ & $\begin{array}{c}2.13 \\
(2.10)\end{array}$ & $\begin{array}{c}0.74 \\
(1.07)\end{array}$ & $\begin{array}{l}3.40 * \\
(2.55)\end{array}$ & $\begin{array}{c}88.06 * * * \\
(4.72)\end{array}$ & $\begin{array}{c}0.88 \\
(1.17)\end{array}$ & $\begin{array}{c}1.23 \\
(1.56)\end{array}$ & $\begin{array}{c}0.34 \\
(0.67)\end{array}$ \\
\hline & 6 & $\begin{array}{l}4.46^{*} \\
(3.19)\end{array}$ & $\begin{array}{l}3.33^{*} \\
(2.45)\end{array}$ & $\begin{array}{c}1.39 \\
(1.25)\end{array}$ & $\begin{array}{l}3.73 * \\
(2.53)\end{array}$ & $\begin{array}{c}82.77 * * * \\
(5.01)\end{array}$ & $\begin{array}{c}2.13 \\
(1.67)\end{array}$ & $\begin{array}{c}1.49 \\
(1.56)\end{array}$ & $\begin{array}{c}0.70 \\
(0.98)\end{array}$ \\
\hline & 9 & $\begin{array}{l}4.60 * \\
(3.27)\end{array}$ & $\begin{array}{l}3.57 * \\
(2.58)\end{array}$ & $\begin{array}{c}1.56 \\
(1.42)\end{array}$ & $\begin{array}{l}3.78 * \\
(2.48)\end{array}$ & $\begin{array}{c}81.81 * * * \\
(5.15)\end{array}$ & $\begin{array}{l}2.31 * \\
(1.77)\end{array}$ & $\begin{array}{c}1.60 \\
(1.48)\end{array}$ & $\begin{array}{c}0.77 \\
(1.03)\end{array}$ \\
\hline & 12 & $\begin{array}{l}4.71 * \\
(3.25)\end{array}$ & $\begin{array}{l}3.69 * \\
(2.62)\end{array}$ & $\begin{array}{c}1.58 \\
(1.44)\end{array}$ & $\begin{array}{l}3.79 * \\
(2.47)\end{array}$ & $\begin{array}{c}81.40 * * * \\
(5.21)\end{array}$ & $\begin{array}{l}2.38 * \\
(1.78)\end{array}$ & $\begin{array}{c}1.65 \\
(1.47)\end{array}$ & $\begin{array}{c}0.80 \\
(1.09)\end{array}$ \\
\hline & 15 & $\begin{array}{l}4.75^{*} \\
(3.24)\end{array}$ & $\begin{array}{l}3.78 * \\
(2.63)\end{array}$ & $\begin{array}{c}1.61 \\
(1.45)\end{array}$ & $\begin{array}{l}3.80 * \\
(2.46)\end{array}$ & $\begin{array}{c}81.15 * * * \\
(5.25)\end{array}$ & $\begin{array}{l}2.40 * \\
(1.78)\end{array}$ & $\begin{array}{c}1.66 \\
(1.46)\end{array}$ & $\begin{array}{c}0.86 \\
(1.11)\end{array}$ \\
\hline & 18 & $\begin{array}{l}4.76^{*} \\
(3.24)\end{array}$ & $\begin{array}{l}3.79 * \\
(2.63)\end{array}$ & $\begin{array}{c}1.61 \\
(1.46)\end{array}$ & $\begin{array}{l}3.80 * \\
(2.46)\end{array}$ & $\begin{array}{c}81.08 * * * \\
(5.26)\end{array}$ & $\begin{array}{l}2.42 * \\
(1.79)\end{array}$ & $\begin{array}{c}1.66 \\
(1.46)\end{array}$ & $\begin{array}{c}0.88 \\
(1.14)\end{array}$ \\
\hline Consistent with theory & & Yes & Yes & No & Yes & Yes & Yes & Yes & Yes \\
\hline \multirow{6}{*}{$\begin{array}{l}\text { Forecast error variance } \\
\text { of ' } m p \text { ' as explained by } \\
\text { shocks }\end{array}$} & 3 & $\begin{array}{l}4.16^{*} \\
(2.94)\end{array}$ & $\begin{array}{c}1.00 \\
(1.08)\end{array}$ & $\begin{array}{c}4.62 * * \\
(2.49)\end{array}$ & $\begin{array}{c}0.99 \\
(1.44)\end{array}$ & $\begin{array}{c}1.90 \\
(1.64)\end{array}$ & $\begin{array}{c}84.45^{* * * *} \\
(4.71)\end{array}$ & $\begin{array}{c}1.88 \\
(2.06)\end{array}$ & $\begin{array}{c}1.00 \\
(1.36)\end{array}$ \\
\hline & 6 & $\begin{array}{l}4.13^{*} \\
(2.92)\end{array}$ & $\begin{array}{c}1.67 \\
(1.66)\end{array}$ & $\begin{array}{c}4.77 * * \\
(2.47)\end{array}$ & $\begin{array}{c}1.94 \\
(2.03)\end{array}$ & $\begin{array}{l}2.63 * \\
(1.94)\end{array}$ & $\begin{array}{c}81.22 * * * \\
(5.19)\end{array}$ & $\begin{array}{c}2.54 \\
(2.40)\end{array}$ & $\begin{array}{c}1.10 \\
(1.41)\end{array}$ \\
\hline & 9 & $\begin{array}{l}4.39 * \\
(2.96)\end{array}$ & $\begin{array}{c}1.80 \\
(1.63)\end{array}$ & $\begin{array}{c}4.69 * * \\
(2.43)\end{array}$ & $\begin{array}{c}1.92 \\
(2.00)\end{array}$ & $\begin{array}{l}2.73 * \\
(1.90)\end{array}$ & $\begin{array}{c}79.16^{* * * *} \\
(5.39)\end{array}$ & $\begin{array}{c}3.37 \\
(2.63)\end{array}$ & $\begin{array}{c}1.94 \\
(1.90)\end{array}$ \\
\hline & 12 & $\begin{array}{l}4.50 * \\
(2.98)\end{array}$ & $\begin{array}{c}1.84 \\
(1.61)\end{array}$ & $\begin{array}{c}4.68 * * \\
(2.42)\end{array}$ & $\begin{array}{c}1.93 \\
(2.00)\end{array}$ & $\begin{array}{l}2.79 * \\
(1.90)\end{array}$ & $\begin{array}{c}78.80 * * * \\
(5.46)\end{array}$ & $\begin{array}{l}3.47 * \\
(2.64)\end{array}$ & $\begin{array}{c}1.99 \\
(1.90)\end{array}$ \\
\hline & 15 & $\begin{array}{l}4.50 * \\
(2.98)\end{array}$ & $\begin{array}{c}1.89 \\
(1.60)\end{array}$ & $\begin{array}{c}4.68 * * \\
(1.51)\end{array}$ & $\begin{array}{c}1.93 \\
(2.00)\end{array}$ & $\begin{array}{l}2.80 * \\
(1.88)\end{array}$ & $\begin{array}{c}78.58 * * * \\
(5.50)\end{array}$ & $\begin{array}{l}3.53 * \\
(2.64)\end{array}$ & $\begin{array}{c}2.09 \\
(1.97)\end{array}$ \\
\hline & 18 & $\begin{array}{l}4.51 * \\
(2.98)\end{array}$ & $\begin{array}{c}1.89 \\
(1.60)\end{array}$ & $\begin{array}{c}4.68 * * \\
(2.42)\end{array}$ & $\begin{array}{c}1.93 \\
(2.00)\end{array}$ & $\begin{array}{l}2.81 * \\
(1.88)\end{array}$ & $\begin{array}{c}78.55^{* * * *} \\
(5.51)\end{array}$ & $\begin{array}{l}3.53 * \\
(2.64)\end{array}$ & $\begin{array}{c}2.10 \\
(1.97)\end{array}$ \\
\hline Consistent with theory & & Yes & No & Yes & No & Yes & Yes & Yes & No \\
\hline \multirow{2}{*}{$\begin{array}{l}\text { Forecast error variance } \\
\text { of 'liq' as explained by } \\
\text { shocks }\end{array}$} & 3 & $\begin{array}{c}0.29 \\
(0.71)\end{array}$ & $\begin{array}{c}1.88 \\
(2.03)\end{array}$ & $\begin{array}{c}1.07 \\
(1.32)\end{array}$ & $\begin{array}{c}0.33 \\
(0.90)\end{array}$ & $\begin{array}{c}2.64 * * \\
(1.56)\end{array}$ & $\begin{array}{c}0.77 \\
(1.04)\end{array}$ & $\begin{array}{c}92.91 * * * \\
(3.20)\end{array}$ & $\begin{array}{c}0.10 \\
(0.45)\end{array}$ \\
\hline & 6 & 1.53 & 3.74 & 1.68 & 1.35 & $3.75^{*}$ & 2.52 & $82.04 * * *$ & $3.41 *$ \\
\hline
\end{tabular}




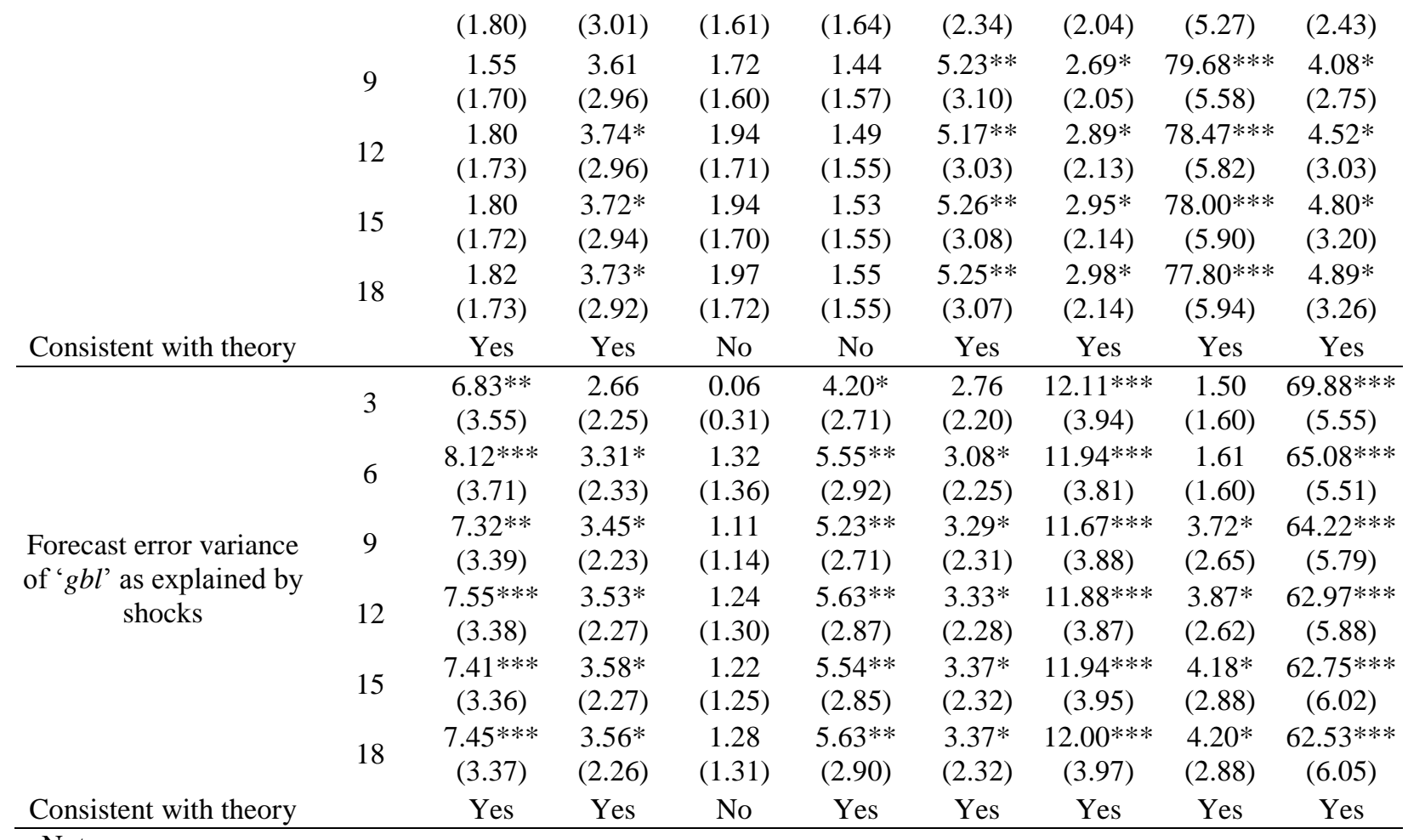

Notes:

a) The "consistent with theory" comments are based on the following decision rules. Any estimation result that is statistically significant and in accordance with macroeconomic theory is denoted "yes". The reason is that macroeconomic theory posits that a relationship exists and the empirical results also support the existence of this relationship. In contrast, any estimation result that is statistically insignificant whereas macroeconomic theory suggests that a relationship exists is denoted "no". The reason is that theoretically one would expect a relationship to exist, however the empirical results find no evidence of a relationship between the variables.

b) Figures in brackets are standard errors and ***, *** indicate significance at $1 \%, 5 \%$ and $10 \%$ respectively.

c) com: International commodity price inflation (global inflation); ffrate: (Change in) Federal funds rate; outputgap: Output gap; inf: WPI inflation; neer: (Change in) Nominal effective exchange rate; $m p$ : monetary policy instrument (which is CMR: Call money rate here); liq: liquidity growth; gbl: Growth of bank lending (or credit). 
Appendix: Figures

Figure A1: Estimated Monetary Policy Shocks

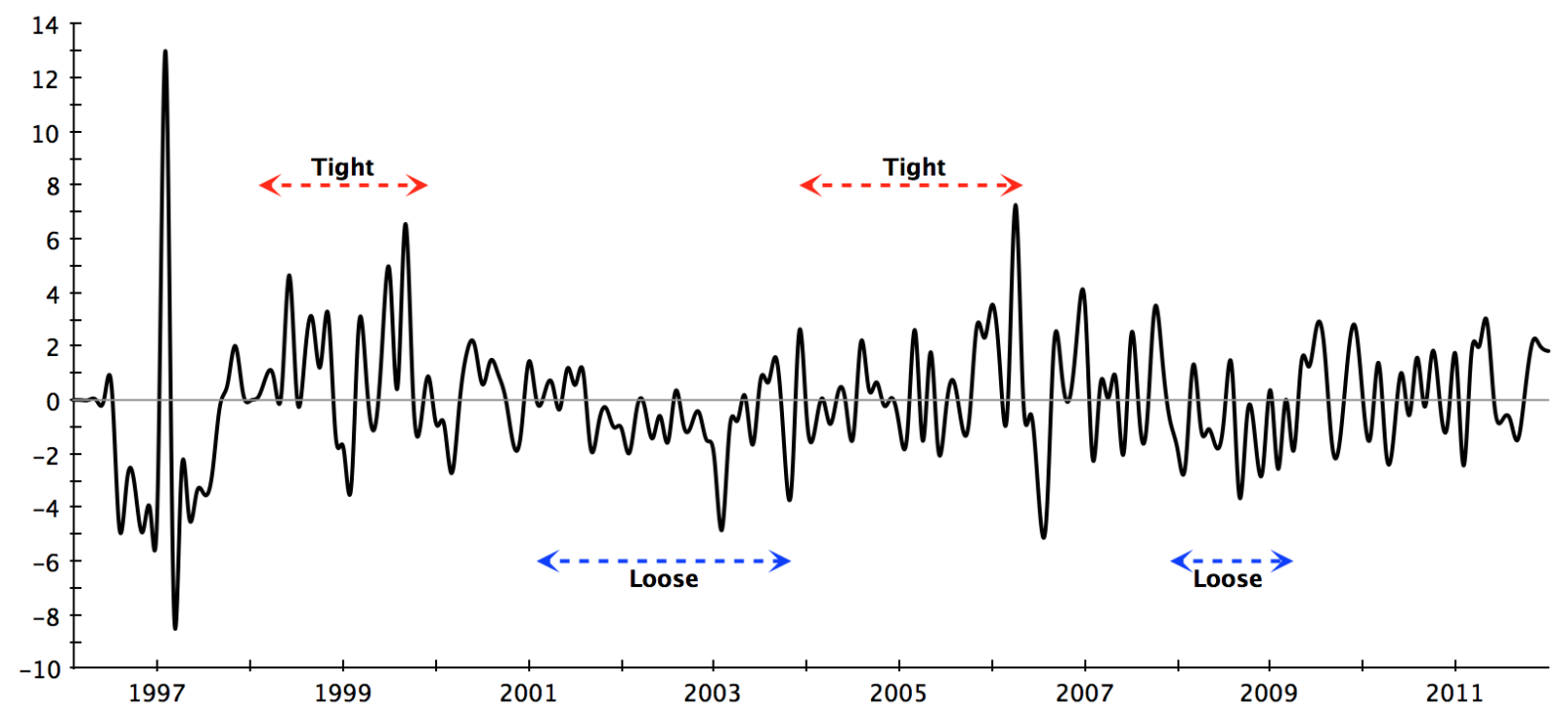


Figure A2: Identification of Monetary Policy Shock

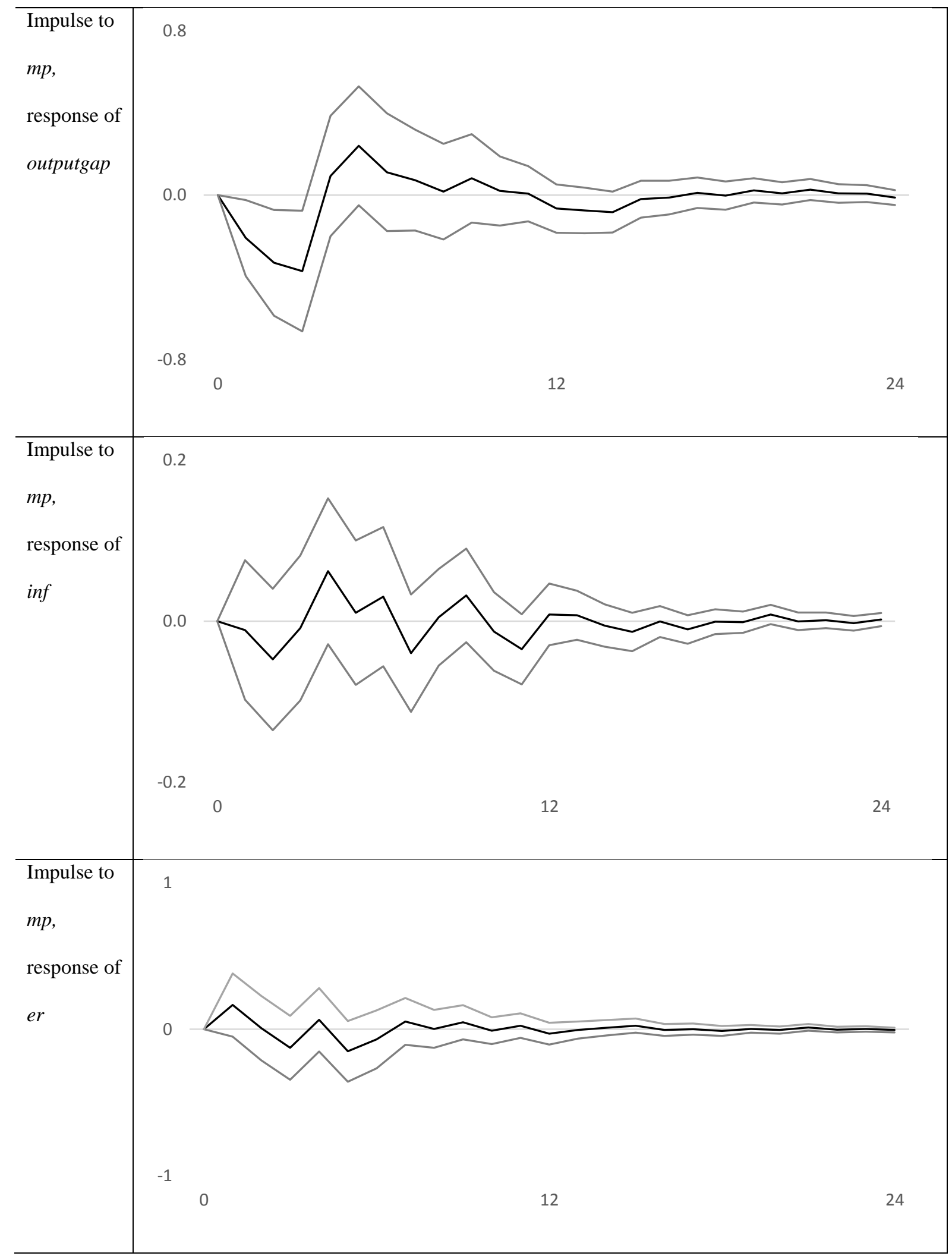

Note: ' $m p$ ' refers to monetary policy instrument which is call money rate in our case; 'outputgap' is difference between (log of) gross domestic product (GDP) at factor cost and its (log of) Hodrick-Prescott trend); 'inf' is the inflation rate (measured by Wholesale Price Index (WPI); 'er' is the (change in) Nominal effective exchange rate. 
Figure A3: Structural Impulse Response Functions-Benchmark case

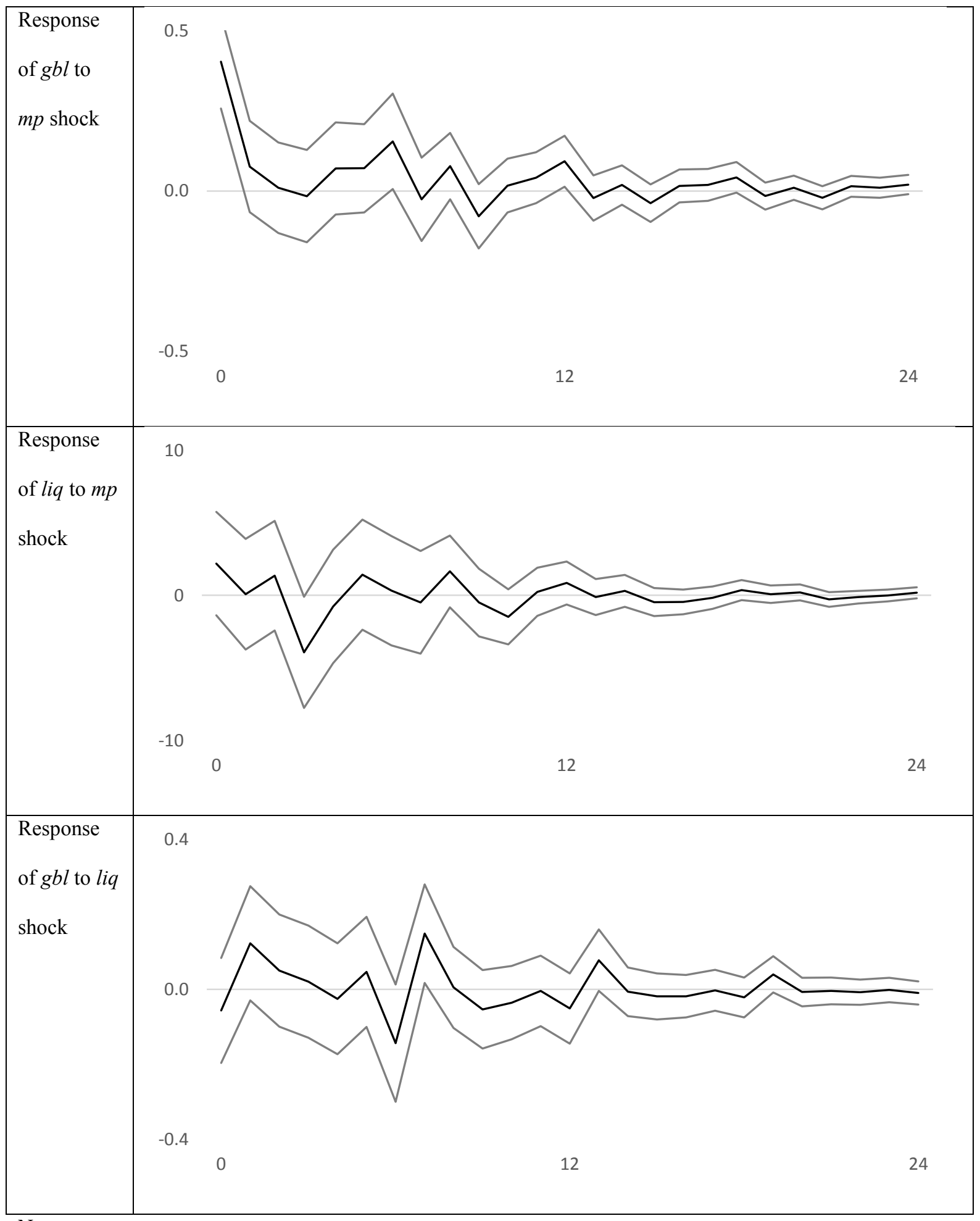

Notes:

(a) ' $m p$ ' refers to monetary policy instrument which is call money rate in our case; ' $g b l$ ' is growth of bank lending (or credit) and ' $l i q$ ' is growth rate of liquidity index as constructed by the authors (refer to equation 2 in the text). 
Figure A4: Structural Impulse Response Functions-Alternative case

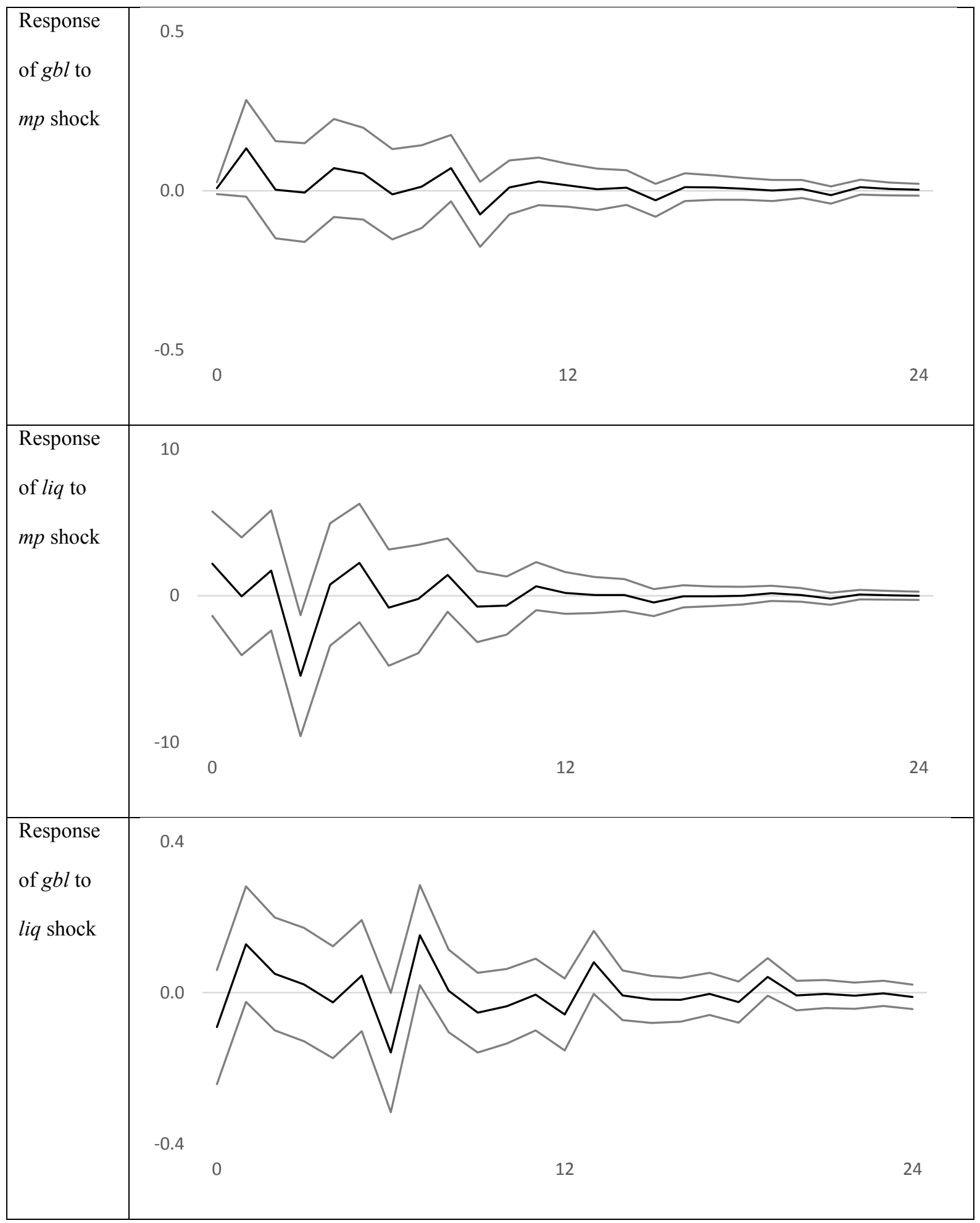

Notes:

(a) Alternative case is where there is no contemporaneous feedback from monetary policy to bank lending (refer to equation 3 in text).

(b) ' $m p$ ' refers to monetary policy instrument which is call money rate in our case; ' $g b l$ ' is growth of bank lending (or credit) and ' liq' is growth rate of liquidity index as constructed by the authors (refer to equation 3 in text). 


\section{References}

Aleem, A. (2010). Transmission mechanism of monetary policy in India. Journal of Asian Economics, 21, 186-197.

Ashcraft, A. (2006). New evidence on the lending channel. Journal of Money, Credit, and Banking, 38(3), 751-75.

Bernanke, B., \& Blinder, A. (1992). The federal funds rate and the channels of monetary transmission. American Economic Review, 82(4), 901-21.

Bhaumik, S. K., Dang, V., \& Kutan, A. M. (2011). Implications of bank ownership for the credit channel of monetary policy transmission: Evidence from India. Journal of Banking and Finance, 35, 2418-2428.

Bhaumik, S. K., \& Piesse, J. (2008). Does lending behaviour of banks in emerging economies vary by ownership? Evidence from the Indian banking sector. Economic Systems, 32, 177196.

Bluedorn, J. C., Bowdler, C., \& Koch, C. (2013). Heterogeneous bank lending responses to monetary policy: New evidence from a real-time identification. International Monetary Fund Working Paper 13/118, May 2013.

Cetorelli, N., \& Goldberg, L. (2012). Follow the money: Quantifying domestic effects of foreign bank shocks in the great recession. NBER Working Paper 17873, February 2012. 
Clarida, R. (2001). The empirics of monetary policy rules in open economies. International Journal of Finance and Economics, 6, 315-323.

Correa-Lopez, M., Garcia-Serrador, A., \& Mingorance-Arnaiz, C. (2014). Product market competition, monetary policy regimes and inflation dynamics: Evidence from a panel of OECD countries. Oxford Bulletin of Economics and Statistics, 76(4), 484-509.

Das, S. (2015). Monetary policy reform in India: Transmission to bank interest rates. International Monetary Fund Working Paper WP/15/129.

Das, A., Mishra, P., \& Prabhala, N. (2015). The transmission of monetary policy within banks: Evidence from India. CAFRAL working paper.

Drakos, A.A., \& Kouretas, G.P. (2015). Bank ownership, financial segments and the measurement of systematic risk: An application of CoVar. International Review of Economics and Finance, 40, 127-140.

Gadanecz, B., \& Jayaram, K. (2009). Measures of financial stability: A review. IFC Bulletin, 31, 365-380.

Gambacorta, L., \& Marqués-Ibanez, D. (2011). The bank lending channel: Lessons from the crisis. Economic Policy, 26(66), 135-182.

Gokarn S., \& Singh, B. ( 2011). External factors and monetary policy: Indian evidence. BIS papers No. 57. 
Hair, J., Anderson, R., \& Tatham, R. (1995). Multivariate Data Analysis. (4 ${ }^{\text {th }}$ ed.). Upper Saddle River, NJ: Prentice-Hall Inc.

Hayashi, F. (2000). Econometrics. Princeton, NJ: Princeton University Press.

Igan, D., Kabundi ,A., Nadal De Simone, F. \& Tamirisa, N. (2013). Monetary policy and balance sheets. International Monetary Fund Working Paper 13/158.

International Monetary Fund. Financial Soundness Indicators Compilation Guide (2006). http://www.imf.org/external/pubs/ft/fsi/guide/2006/

Jayaratne, J., \& Morgan, D. (2000). Capital market frictions and deposit constraints at banks. Journal of Money, Credit, and Banking, 32, 74-92.

Jonas, M. (2014). Is US bank lending sensitive to exchange rates? A panel data investigation. Modern Economy, 5, 848-863.

Kannan, R., Sanyal, S., \& Bhoi, B. B. (2007). Monetary conditions index for India. The RBI Occasional Papers, 27, No.3

Kashyap, A., \& Stein, J. (2000). What do a million observations on banks say about the transmission of monetary policy? American Economic Review, 90(3), 407-28. 
Khan, H.H., Ahmad, R.B., \&Gee, C.S. (2016). Bank competition and monetary policy transmission through the bank lending channel: Evidence from ASEAN. International Review of Economics and Finance, 44, 19-39.

Khwaja, A., \& Mian, A. (2008). Tracing the impact of bank liquidity shocks: Evidence from an emerging market. American Economic Review 98, 1413-1442.

Kishan, R., \& Opiela, T. (2006). Bank capital and loan asymmetry in the transmission of monetary policy. Journal of Banking and Finance, 30(1), 259-285.

Kishan, R., and Opiela ,T. (2000). Bank size, bank capital, and the bank lending channel. Journal of Money, Credit, and Banking, 32 (1), 121-41.

Kwapil, C., \& Scharler, J. (2013). Expected monetary policy and the dynamics of bank lending rates. International Review of Economics and Finance, 27, 542-551.

Mishkin, F. (1996). The channels of monetary transmission: Lessons for monetary policy. NBER Working Paper No. 5464.

Mishra, A. (2013). Pre-conditions for inflation targeting in an emerging economy: The case of India. Global Economy Journal, 13(3), 89-108.

Mishra, A., \& Mishra,V. (2012). Inflation targeting in India: A comparison with the multiple indicator approach. Journal of Asian Economics, 23(1), 86-98. 
Moosa, I., \& Burns, K. (2012). Interpolating flow and stock variables in a continuous-time dynamic framework. Applied Economics Letters, 20(7), 621-625.

Morgan, D. (1998). The credit effects of monetary policy: Evidence using loan commitments. Journal of Money, Credit, and Banking, 30(1), 102-18.

Nachane, D.M., Ghosh, S. \& Ray, P. (2006). Basel II and bank lending behaviour: Some likely implications for monetary policy. Economic and Political Weekly, 41(11), 1053-1058. The Reserve Bank of India (RBI). Report on Currency and Finance (1996-97, 1998-99, 19992000 , 2003-2004, 2005-2006, 2006-07, 2009-2010)

https://www.rbi.org.in/Scripts/Publications.aspx?publication=Annual

The Reserve Bank of India (RBI). Report on Trend and Progress of banking in India (200708, 2008-09, 2009-10) https://www.rbi.org.in/Scripts/Publications.aspx?publication=Annual

The Reserve Bank of India (RBI). Manual on Financial and Banking Statistics (2007). http://rbidocs.rbi.org.in/rdocs/Publications/PDFs/78900.pdf

The Reserve Bank of India (RBI). Financial Stability Report (2010). http://rbidocs.rbi.org.in/rdocs/PublicationReport/Pdfs/FSR301210F.pdf

The Reserve Bank of India (RBI). Handbook of Statistics of Indian Economy (2013). http://rbidocs.rbi.org.in/rdocs/Publications/PDFs/FHB160913FLS.pdf 
The Reserve Bank of India (RBI). Financial Stability Report (2014). https://rbi.org.in/scripts/PublicationReportDetails.aspx?UrlPage=\&ID=795

The Reserve Bank of India (RBI). Report of the expert committee to revise and strengthen the monetary policy framework (2014).

https://rbidocs.rbi.org.in/rdocs/PublicationReport/Pdfs/ECOMRF210114_F.pdf

Scharler, J. (2008). Bank lending and the stock market's response to monetary policy shocks. International Review of Economics and Finance, 17, 425-435.

Schnabl, G. (2012). Monetary policy reform in a world of central banks. Global Financial Markets Working Paper 26.

Sims, C. (1980). Macroeconomics and reality. Econometrica, 48, 1-48.

Singh, K., \& Kalirajan, K. (2007). Monetary transmission in the post-reform India: An evaluation. Journal of the Asia Pacific Economy, 12(2), 158-187.

Taylor, J. (1993). Discretion versus policy rules in practice. Carnegie-Rochester Conference Series on Public Policy, 39, 195-214.

Virmani, V. (2004). Operationalising Taylor-type rules for the Indian economy: Issues and some results (1992q3 2001q4). IIMA Working Paper 2004-07-04. 
Williams, B., Brown, T., \& Onsman, A. (2012). Exploratory factor analysis: A five-step guide for novices. Australasian Journal of Paramedicine, 8(3), 1-13. 